\title{
The First 40 Years of AIDS: Promising Programs, Limited Success
}

\author{
William W. Darrow ${ }^{1}$ (D) \\ Accepted: 8 October 2021 / Published online: 26 October 2021 \\ (c) The Author(s), under exclusive licence to Springer Science+Business Media, LLC, part of Springer Nature 2021
}

\begin{abstract}
HIV-prevention program planning, implementation, and evaluation began in the United States shortly after reports of a mysterious, apparently acquired, immune deficiency syndrome appeared in summer 1981. In San Francisco, New York City, and elsewhere, members of LGBT communities responded by providing accurate information, giving support, and raising money. During the first decade of the AIDS pandemic (1981-1990), social and behavioral scientists contributed by designing theory-based and practical interventions, combining interventions into programs, and measuring impact on behavior change and HIV incidence. In the second decade (1991-2000), federal, state, and local agencies and organizations played a more prominent role in establishing policies and procedures, funding research and programs, and determining the direction of intervention efforts. In the third decade (2001-2010), biomedical interventions were prioritized over behavioral interventions and have dominated attempts in the fourth decade (2011-2020) to integrate biomedical, behavioral, and structural interventions into coherent, efficient, and cost-effective programs to end AIDS.
\end{abstract}

Keywords Behavior change $\cdot$ Impact $\cdot$ Intervention $\cdot$ Outcome $\cdot$ Risk Reduction

\section{Resumen}

La planificación, implementación y evaluación de programas de prevención del VIH comenzaron en los Estados Unidos poco después de que aparecieran informes de un misterioso síndrome de inmunodeficiencia aparentemente adquirida en el verano de 1981. En San Francisco, la ciudad de Nueva York y otros lugares, los miembros de las comunidades LGBT respondieron proporcionando información precisa, apoyo y recaudación de fondos. Durante la primera década de la pandemia del SIDA (1981-1990), los científicos sociales y del comportamiento contribuyeron diseñando intervenciones prácticas y basadas en la teoría, combinando intervenciones en programas y midiendo el impacto en el cambio de comportamiento y la incidencia del VIH. En la segunda década (1991-2000), las agencias y organizaciones federales, estatales y locales desempeñaron un papel más destacado en el establecimiento de políticas y procedimientos, la financiación de investigaciones y programas y la determinación de la dirección de los esfuerzos de intervención. En la tercera década (2001-2010), las intervenciones biomédicas se le dieron prioridad sobre las intervenciones conductuales y han dominado los intentos en la cuarta década (2011-2020) de integrar intervenciones biomédicas, bio conductuales y estructurales en programas coherentes, eficientes y económicos para acabar con el SIDA.

History will recall, Reagan and Bush did nothing at all. George Bush, you can't hide. We charge you with genocide. Bringing the dead to your door. We won't take it anymore. (Ashes Action chant of desperate and dying men and women; gay, lesbian and straight supporters, and their loved ones, outside the gates of the White House, District of Columbia, October 11, 1992) Source: ACT UP Historical Archive (https://actupny.org/divatv/ synopsis75.html). Accessed 14 Oct 2021.

\section{Introduction}

After AIDS was first detected in 1981 [1], public health authorities struggled to understand what occurred, why, and-most important-what to do to prevent new cases from occurring $[2,3]$. When I joined the Centers for Disease

William W. Darrow

darroww@fiu.edu

1 Behavioral Research and Evaluation Consultants, LLC, 4552

Post Avenue, Miami Beach, Florida, FL 33140, USA 
Control and Prevention's (CDC) Task Force on Kaposi's Sarcoma and Opportunistic Infections for its inaugural meeting on June 18, 1981, my assignment was to help discover what was causing an unprecedented outbreak of bizarre opportunistic infections among people without underlying immune system disorders. Once we learned that cause, we could find ways to prevent the suffering and death AIDS inevitably brought with it in those early days.

Now as we look back on 40 years of those efforts, my aim is to review and assess some of the programs created over the past 40 years to prevent the spread of HIV in communities and bring the HIV/AIDS epidemic in the United States (US) under control. To protect public health, we rely on programs to bring about behavioral, social, and cultural change [4-6]. Programs consisting of one or more interventions have been designed, developed, and implemented with varying degrees of success in achieving their stated objectives $[7,8]$.

If we were to imagine our HIV-prevention efforts as a ship racing to aid individuals tossed unwittingly into a stormy sea, we would come to realize that our vessel has frequently been blown off course. By critiquing the fourdecade history of bewildering shifts in program priorities, baffling decisions to act at times and not at other times, and disappointing outcomes of many interventions designed to interrupt HIV transmission, my goal in this Commentary is to provide insights that could improve the collaborative processes of planning, implementing, evaluating, and, ultimately, increasing the effectiveness of HIV-prevention programs.

\section{Beginnings: 1981-1990}

The AIDS pandemic likely began with the silent spread of an undetected pathogen in sub-Saharan Africa in the early years of the 20th century [9]. The infectious agent-labelled "lymphadenopathy-associated virus" (LAV) when it was discovered in 1983 [10] and designated "human immunodeficiency virus" (HIV) by the International Committee on Taxonomy of Viruses in 1986 [11] — arrived on the island of Hispaniola (which is divided into the nations of Haiti and the Dominican Republic) in the 1960s and spread from there to the North American continent [12, 13]. Early infections in New York City primarily occurred among men who engaged in anal intercourse with other men and people who injected drugs (PWID) [14]. As HIV began to destroy their immune systems, individuals who had contracted HIV began to develop a range of conditions associated with severe immune deficiency, including Kaposi's sarcoma (KS), Pneumocystis pneumonia (PCP), and other opportunistic infections (OIs) that would come to define AIDS. Effective combination therapy would not arrive until 1996, and few of those infected before that time survived the devastating effects of HIV.

\section{Recognition}

Even before the "official" recognition of what would come to be known as AIDS, a growing number of people were already concerned. On May 18, 1981, Dr. Lawrence Mass, a health columnist for the New York Native, noted, "Last week there were rumors that an exotic new disease had hit the gay community in New York. From the New York City Department of Health, Dr. Steve Phillips explained that the rumors are for the most part unfounded" [15]. Three weeks later, on June 5, a report published in CDC's Morbidity and Mortality Weekly Report (MMWR) described 5 cases of PCP among young, previously healthy, homosexual men in Los Angeles [16]. This report would come to be seen as the "official" recognition of the beginning of the epidemic in the US.

On July 3, 1981, both the MMWR and the New York Times simultaneously published reports of KS outbreaks; 26 cases of KS in MMWR [17] and an article on page A-20 of the New York Times, "Rare Cancer Seen in 41 Homosexuals: Outbreak Occurs Among Men in New York and California" [18]. These reports heralded the recognition of AIDS as a problem of unknown magnitude and consequences. Although it was not taken as a serious threat to the public's health in summer 1981, the "exotic new disease" was real [19].

\section{Response in New York}

Although the first cases were reported in Los Angeles, New York would be the earliest epicenter of the AIDS epidemicand the community response would take place very early in the process. On August 11, 1981, over 80 gay men met in playwright and author Larry Kramer's apartment to discuss the strange illnesses affecting their friends and lovers and to raise funds for research [20]. A few months later, on January 4, 1982, Kramer and 5 other men who attended the earlier meeting created the Gay Men's Health Crisis (GMHC), the first community-based service provider for gay men with AIDS in the US [21]. Over time, GMHC responded to the fears and anguish of members of the lesbian, gay, bisexual, and transgender (LGBT) community and their families by providing support, offering workshops, and teaching prevention practices and interpersonal negotiation skills [22].

HIV spread quickly in the absence of behavioral interventions. On the community side, two New York activists who were living with AIDS, Michael Callen and Richard Berkowitz, would attempt to address the behaviors that appeared to be driving the epidemic in their 1983 selfpublished book, How to Have Sex in an Epidemic: One 
Approach [23]. But a cohort study of 378 men who have sex with men (MSM) would later show that $6.6 \%$ were infected with HIV in 1978-1979 and the cumulative prevalence of HIV infection continued to increase after 1981 in spite of self-reports of annual decreases in sexual activity [24]. The dearth of information about the agent causing AIDS, the lack of any significant government intervention or assistance to the populations hardest hit in the early days of the epidemic (MSM and PWID) by the city of New York, and the long latency period of HIV would contribute to staggering numbers of cases in the years to come.

Frustrated with the lack of progress in discovering a safe and effective treatment, vaccine, or cure for AIDS, Larry Kramer and other activists established the AIDS Coalition to Unleash Power (ACT UP) in 1987 to protest the slow pace of scientific research, engage in civil disobedience, and "get drugs into bodies" [25].

\section{Response in San Francisco}

Members of San Francisco's LGBT community were among the first to respond to early rumors and subsequent reports of a previously unrecognized "gay-related immune deficiency" syndrome [26]. There were multiple community efforts to address the burgeoning epidemic. In June 1982, the Sisters of Perpetual Indulgence, a gay-rights activist group, prepared and distributed a sexually explicit booklet, Play Fair!, to draw attention to sexually transmitted infections (STIs) and demonstrate how to prevent acquiring them [27]. The Kaposi's Sarcoma Research and Education Foundation (later the San Francisco AIDS Foundation) was formed in May 1982 [28], and joined other local health services organizations (like the Shanti Project-an organization formed in the early 1970s to support people with cancer) to provide helpful information, social services, and risk-reduction behavior-change programs under the umbrella of a collaborative community-mobilization project called "Stop AIDS San Francisco" [29].

By late 1983, community mobilization began to result in gradual reductions in high-risk sexual behavior [30] and in HIV incidence among gay and bisexual men [31, 32]. The Stop AIDS program in San Francisco was built on the belief that "the most effective communication campaigns make use of multiple communication channels" [33, p. 157] and on the premise that "community-based AIDS prevention campaigns are most effective in bringing about rapid, large-scale, behavior change" [33, p. 160]. The program maximized community mobilization to minimize HIV transmission.

"The centerpiece of the campaign was the effort to promote interpersonal communication about the epidemic, its impact, and meaning" [33, p. 162]. Mass-media messages, testing, and individual counseling were assigned secondary roles. "In AIDS prevention, the task is to access informal peer networks among communities of individuals who are at high risk of infection" [33, p. 163]. "The Stop AIDS project used hundreds of volunteers to reach 25,000 men in face-to-face sidewalk conversations about AIDS prevention. Seven thousand attended evening-long, peer-facilitated, Stop AIDS meetings in homes throughout the city" [33, p. 162]. Reported risk behaviors declined, rates of STIs fell, and many sex clubs closed because of declining patronage.

Investigators at the University of California, Berkeley School of Public Health, and University of California, San Francisco (UCSF) School of Medicine, were involved in early biomedical and epidemiological research on AIDS prevention. When the UCSF Center for AIDS Prevention Studies (CAPS) was established in 1986, CAPS researchers began focusing on social, behavioral, and policy research [34]. CAPS behavioral scientists developed the AIDS Risk-Reduction Model, which posited 3 stages of behavior change: (1) labeling of high-risk behaviors as problematic, (2) making a commitment to reducing high-risk behaviors, and (3) seeking and enacting solutions directed at reducing high-risk activities [35]. In addition, the peer-led Mpowerment program subsequently developed by CAPS researchers successfully reduced high-risk sexual activities among young gay men on the West Coast. It consisted of multiple components: outreach, educational workshops with small groups, and a publicity campaign [36].

\section{Response from the Centers for Disease Control and Prevention}

In 1981, CDC, with its partners in state, municipal, and territorial health departments, (1) developed a case definition for AIDS and collected 159 case reports, (2) conducted a case-control study of homosexual and bisexual men (CDC AIDS Project 1) [37], and (3) carried out a series of other investigations to help identify the cause of the outbreak [38]. Based on findings from AIDS surveillance and observational epidemiologic studies, CDC, the Food and Drug Administration (FDA), and the National Institutes of Health (NIH) issued interagency guidelines for the prevention of AIDS in March 1983 [39]. Following the identification of LAV in May 1983 [10] and licensing of ELISA (enzyme-linked immunosorbent assay) and Western blot tests for HIV antibodies in 1985 [40], CDC began to support health education for risk-reduction (HE/RR) and counseling, testing, referral, and partner notification (CTRPN) programs in health department clinics and other sites [41].

\section{Response from the US Public Health Service}

The US Public Health Service's (USPHS) plan to prevent and control AIDS was drafted in 1985 [42]. In that draft, the 
USPHS proposed "programs to effect behavior changes for persons at risk" and to provide "up-to-date information on AIDS" with the clearly stated goal of eliminating transmission of HIV by the year 2000 .

The following year, the USPHS plan was expanded [43] to include specifics on how that goal was to be achieved and it was refined once again in 1988 [44]. "A strategy to control and prevent AIDS should involve voluntary counseling and testing for persons at increased risk of [HIV] infection and imparting to infected patients those Public Health Service recommendations concerning personal behaviors that must be observed if spread of the virus is to be halted" [43, pp. 345-6].

Interventions sought to: (1) Raise awareness and educate Americans through "national information and education campaigns...targeted to individuals and groups whose behavior places them at high risk for AIDS." (2) Assure that uninfected persons at increased risk "know how to protect themselves." (3) Provide "culturally sensitive, meaningful information and education" to racial and ethnic minority populations. To assess impact, "[USPHS] should encourage and assist in the evaluation and comparison of all interventions for prevention and control of AIDS" [43, p. 346].

\section{America Responds to AIDS}

On October 22, 1986, US Surgeon General C. Everett Koop introduced his straightforward and nonjudgmental 20-page Surgeon General's Report on AIDS [45]. The Reagan administration followed up in October 1987 by launching a multiphased mass media and social marketing campaign titled America Responds to AIDS (ARTA). And in May 1988, the federal government mailed an 8-page pamphlet, Understanding AIDS, to alert all Americans to the threat of AIDS and what could be done to prevent it (Fig. 1).

Woods et al. [46] described the development of ARTA as "one of the most comprehensive formative research processes in the history of public service campaigns." They added, "Maximum input from all relevant constituencies is obtained to ensure that they support the campaign's objectives and implementation strategy" [46, p. 616]. The overall objective of ARTA was to enlist the media as a partner in the effort to establish a clear national public health agenda on AIDS by reaching as many Americans as possible with disease-prevention information in a credible and acceptable way [47].

A model emerged from the planning process indicating that a combination of techniques, including utilizing the tools offered by the burgeoning field of "social marketing," could result in maximum exposure in both news stories and public affairs programming. The initial results seemed positive. For the government's investment of $\$ 7.36$ million, the media aired public service announcements about ARTA a minimum of 59,113 times between October 1987 through January 1991 "at a commercial value of $\$ 67.8$ million" [46, p. 620].

The nature of the AIDS epidemic called for new strategies to educate the public-but CDC had never been involved in this type of public health campaigning before. In an informal evaluation of ARTA, Bev Schwartz pointed to 5 obstacles that hindered full impact of the ARTA social marketing campaign [48]: (1) Few officials understood the fundamentals of marketing, and few seemed interested in learning about them. (2) Few opportunities were afforded to target messages to specific audiences and build appropriate reach and frequency strategies into the media plan. (3) Dealing with government officials, institutional clearances, and individual approvals took an incredible amount of time "to plan, develop, implement, and evaluate a program" [48, p. 32]. (4) Communication principles and values often took a backseat to science, medicine, and the corporate culture of a federal agency. Her personal reflections also noted: "At CDC, science and epidemiology set the context in which everything evolves. Political climates and agendas need to be managed from the beginning to the end of the marketing process. We must explain strategic marketing principles and objectives as a coordinated, collaborative, and supportive venture" [48, pp. 33-34].

In addition to ARTA, CDC Director James Mason and colleagues [49] described a variety of educational programs that the agency was undertaking to provide support for behavior-change programs that decreased the risk of HIV transmission, including school health education to prevent the spread of HIV among adolescents and AIDS community demonstration projects. In an article assessing AIDS information and education campaigns, Harvard professor Harvey Fineberg [50] suggested that efforts were probably insufficient to achieve the objective of changing sexual behavior to the extent necessary to halt HIV transmission in the US. In February 1988, he wrote: "When social change occurs, the evolution of life-style and habit can unfold over a period of decades, or longer" and "our nation has yet to mount a coordinated, intensive, and comprehensive AIDS prevention program. In this sense," he concluded, "education to prevent AIDS has not been given the full-scale test it deserves" [50, p. 596].

The Presidential Commission on the HIV Epidemic [51] offered an interim report in 1988 that called for a \$20-billion, 10-year effort to fight AIDS, and its final report included 20 major findings and recommendations, "which together comprise a comprehensive national strategy for managing the HIV epidemic.” They included recommendations for: (1) development and implementation of education programs, (2) immediate implementation of preventive measures, such as confidential partner notification, and (3) addressing ethical 

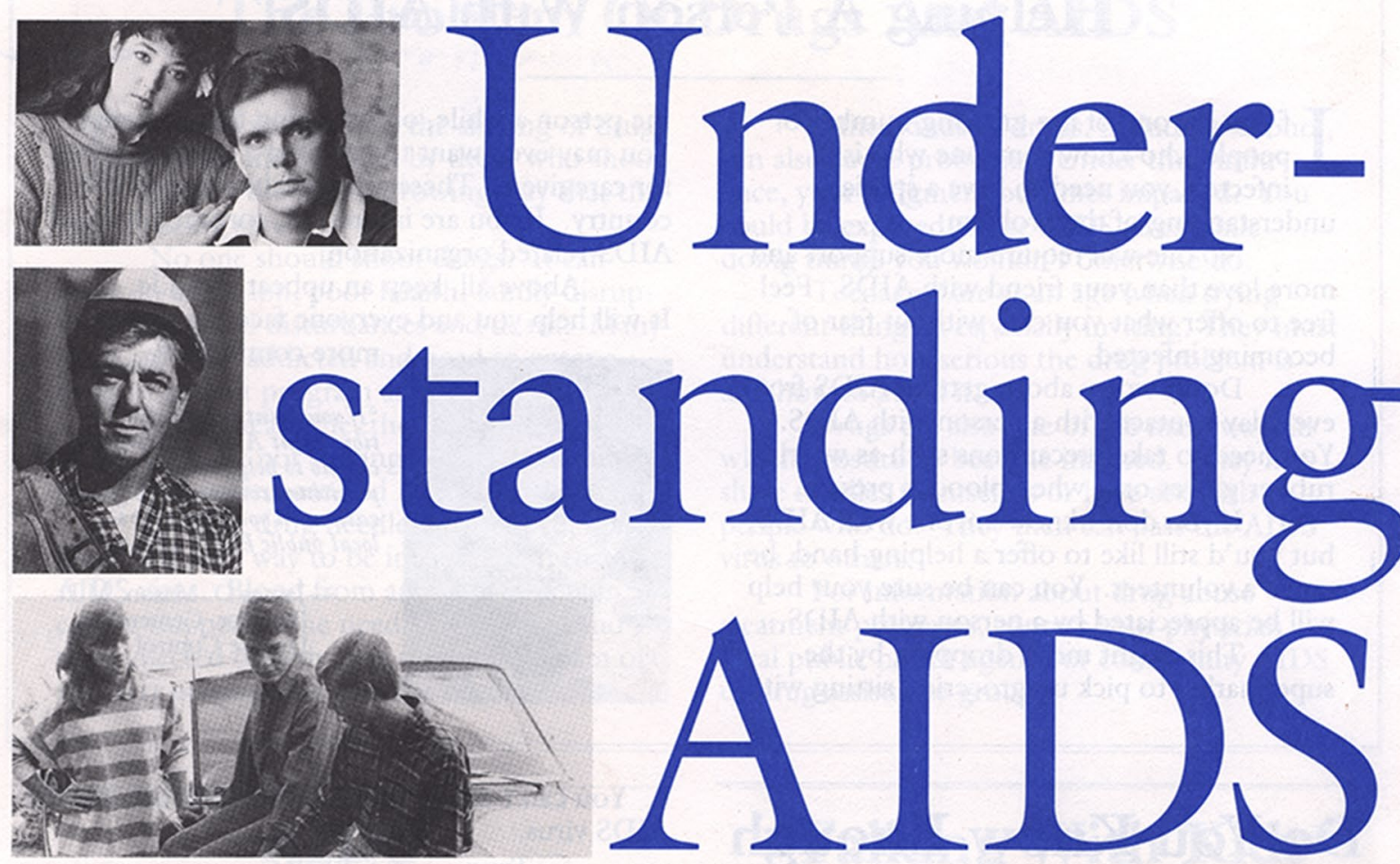

\section{What Do You Really Know About AIDS?}

\section{Are You At Risk?}

\section{AIDS And Sex}

\section{Why No One Has Gotten AIDS From Mosquitoes}

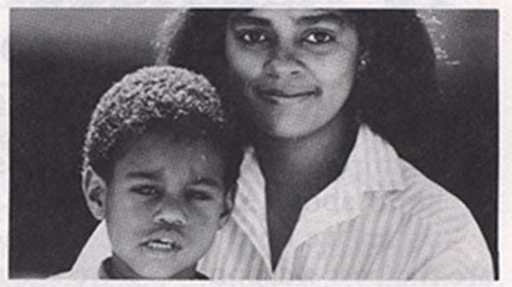

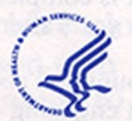

OTIS R. BOWEN, M.D., Secretary U.S. Department of Health and Human Services

\begin{tabular}{|c|}
\hline A M E R I C A \\
\hline RES P O N D S \\
\hline TO.A I D S \\
\hline
\end{tabular}

ROBERT E. WINDOM, M.D.,
Assistant Secretary for Health

U.S. Department of Health and Human Services

This brochure has been prepared by the Surgeon General and the Centers for Disease Control, U.S. Public Health Service. The Centers for Disease Control is the government agency responsible for the prevention and control of diseases, including AIDS, in the United States. 
issues raised by the HIV epidemic. One of the 13 Commission members noted, "We underscored the need to select carefully the blend of education, service, volunteerism, and official action that would take each jurisdiction farthest. One of the enduring lessons of public health is that solutions must be tailored to circumstances, and that local 'ownership' of both problem and solution are essential to long-term success" [52].

On April 28, 1988, by a vote of 87 to 4, the US Senate passed the AIDS Research and Information Act, a first step toward establishing an overall federal AIDS policy [21]. For fiscal 1988, the bill authorized almost $\$ 700$ million in research and education funds to be channeled through CDC and NIH. Two amendments were added, however. One from Senator Jesse Helms prohibited the use of federal AIDS education funds for activities that "promote or encourage, directly, homosexual sexual activity." Another from Senator Edward Kennedy required AIDS education programs to "stress the public health benefits of abstinence and a single monogamous relationship and the avoidance of illegal intravenous drug use." These restrictions severely limited the effectiveness of HIV-prevention programs funded by the US government and supported by CDC. MMWR editors concluded their review of "The HIV/AIDS Epidemic: The First 10 Years" with two prophetic sentences: "AIDS will remain a major public health challenge worldwide in the twenty-first century. Education of all persons about AIDS to prevent transmission of HIV infection is critical to controlling this problem" [53] (Fig. 2).

\section{Assessments, Achievements, and Alterations: 1991-2000}

The first decade of AIDS was marked by transitions from ignorance to awareness, from denial to confrontation, and from stunned inertia to collective action. Social and behavioral scientists, activists, and armies of volunteers contributed to community mobilization efforts and helped to forge programs aimed at beneficial behavioral and social change. Change was apparent as viable programs were assessed, altered, and adapted in the second decade of the AIDS pandemic.

\section{Popular Opinion Leaders}

Smaller cities could not generate the kinds of collective efforts witnessed in major metropolitan areas of the Northeast and on the West Coast. An alternative was to recruit well-known community members and have them endorse risk-reduction behaviors to influence the sexual risk practices of others in their social networks [54-56]. In an intervention city in the southern US, the proportion of men who engaged in unprotected anal intercourse over a 2-month period decreased $25 \%$ (from 36.9 to $27.5 \%$ ), with a $30 \%$ reduction (from 27.1 to $19.0 \%$ ) for unprotected receptive anal intercourse, a $16 \%$ increase in condom use during anal intercourse, and an $18 \%$ decrease in the proportion of survey respondents reporting multiple sexual partners. Population-level changes in risk behavior observed in this series of studies were attributed to natural styles of communication-conversations among members of peer networks about curtailing their risks and changing community norms. Little or no change was observed among men in two comparison cities over the same 2 months [54].

Follow-up studies showed that the "popular opinion leader" model consistently produced reductions of 15 to $29 \%$ from baseline levels for unprotected anal intercourse, with similar patterns replicated in all 3 cities [55]. Statistically significant reductions in the mean frequency of unprotected anal intercourse during the previous months (baseline 1.68 occasions; follow-up 0.59, $\mathrm{p}=0.04$ ) and an increase in the mean percentage of occasions of anal intercourse protected by condoms (baseline $44.7 \%$; follow-up $66.8 \%, p=0.02$ ) were reported. Increased numbers of condoms taken from dispensers in intervention-city bars corroborated risk-behavior self-reports.

\section{Harm Reduction}

The concept of "harm reduction" evolved in the early 1980s in response to increasing hepatitis B virus (HBV) infections among PWID in the Netherlands [57]. The idea was to minimize harm to individual PWID, not abolish substance use. Trusting people to make better choices by providing accurate risk information was central to the approach. Treating "marginalized" and "unpopular" people with dignity turned out to be a viable intervention that could empower change [58]. Evidence of less harm was taken as a measure of success [59]. It led to the creation of one of the best available strategies for reducing the spread of HBV - and later HIVamong PWID: syringe services programs (SSPs), which included syringe exchange.

In addition to offering safe injection equipment, SSPs connected PWID with health care providers who could offer HIV testing, counseling, and treatment. They also reached out to people with addictions and encouraged them to enter and continue treatment for substance use disorders. Humane treatment spurred self-care. Self-care displaced self-destruction. Syringe exchange, as part of a comprehensive prevention program, minimized the risks of HIV, HBV, and hepatitis $C$ virus infections and the spread of these and other blood-borne diseases to others in many places [60].

Evaluating comprehensive harm-reduction programs was difficult because of variations in the component interventions, implementation, and interaction effects [61]. 
Fig. 2 America Responds to AIDS prepared and distributed public service announcements, posters, and other educational materials to encourage young women and other key populations to Talk About AIDS

\section{Talk AboutAIDS}
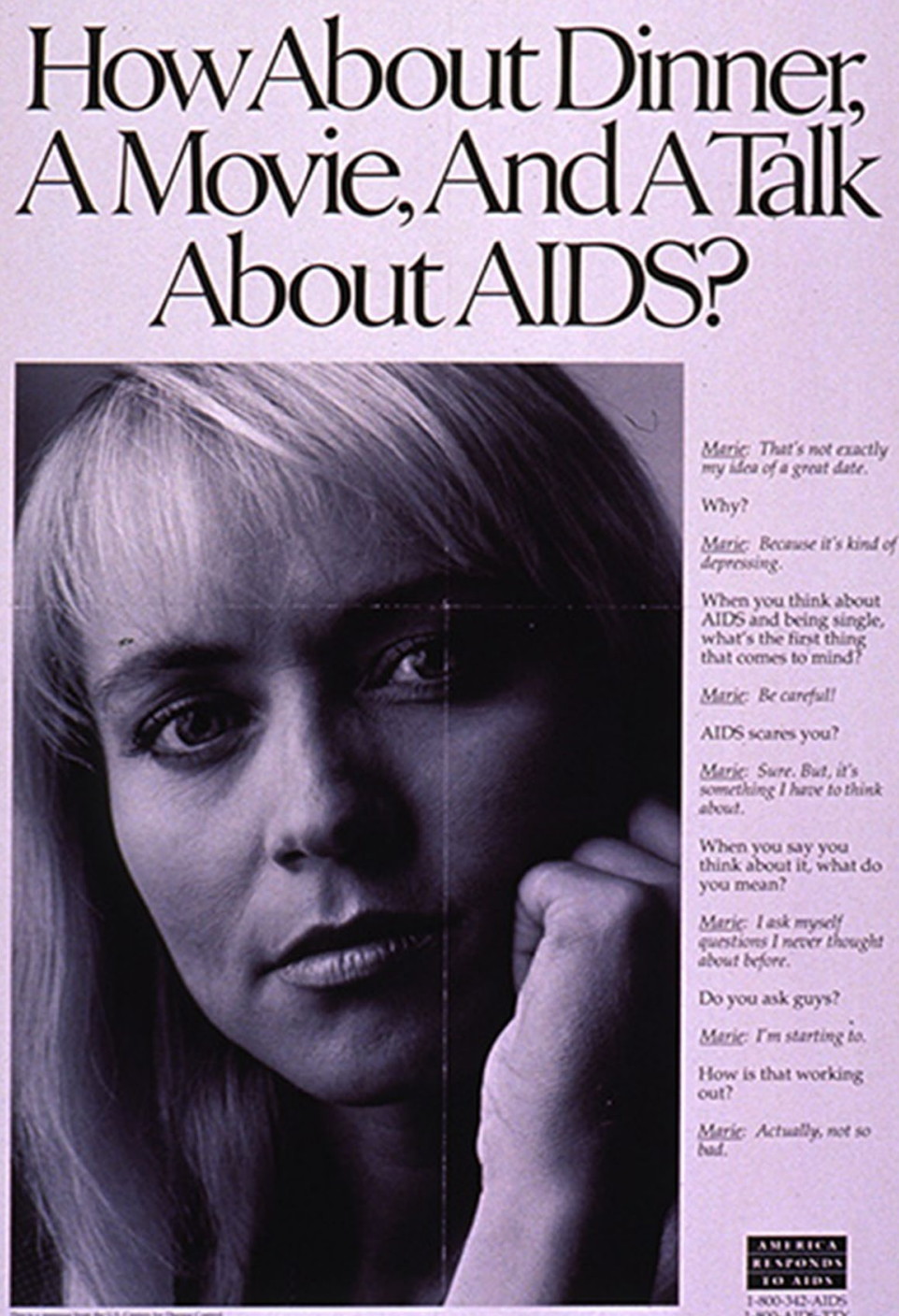

Merie: Thar's not cractly mylica of a grout Late.

Why?

Meric Becruse ir's kind of Jemosing.

When you think about AIDS and being single, whars the first thing thit comsos to mind

Maric Recandult: AIDS scaros you?

Maric Surr. Bat, its

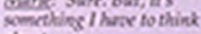
atowt.

When you say you think aboot it what do you meun?

Maric lask myad wotims I mant ingigh atbout togere. Do you ask guys? Meric $r$ m serting in How is that working bow? Moric Actuallys not so as.

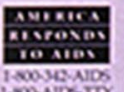

Nevertheless, sterile syringe and medically assisted treatment programs led to reductions in heroin use and HIV incidence [62]. In New York City, PWID began contracting HIV during the mid-1970s and the virus spread rapidly between 1979 and 1983 [14]. From 1984 through 1987, the HIV seroprevalence rate stabilized between 55 and $60 \%$ due to "increasing conscious risk reduction" [14]. The use of potentially contaminated syringes declined from 51 to $7 \%$ of injections after PWID were able to access unsanctioned syringe exchanges [63]. The subsequent authorization of SSPs was critical in the reduction in HIV infections, but community outreach to educate PWID and motivate them to practice safer injection and safer sex also contributed to overall success. Harm-reduction programs were effective in interrupting HIV transmission, especially when they treated PWID with dignity and respect, provided convenient locations and hours of operation, and minimized bureaucratic hassle [64].

\section{AIDS Community Demonstration Projects}

The AIDS Community Demonstration Projects (ACDP) were community-level intervention trials funded by CDC to increase behaviors designed to prevent HIV transmission [65]. Originally established in 1986 to examine the effects of voluntary HIV counseling and testing in clinics and 
storefronts, ACDP adopted a multisite protocol in October 1989. It required formative ethnographic research, a theoretically driven program plan with multiple interventions, and cross-sectional assessments within five intervention and five control communities before, during, and after exposure to role-model stories and other face-to-face interventions delivered by peer volunteers to PWID and their sex partners, sex workers, and other high-risk, hard-to-reach, populations [66].

Over a 3-year period, movement toward consistent condom use during vaginal intercourse with "main (spouse or steady)" and "nonmain (casual, one-time, paying)" partners was greater in intervention than in comparison communities. The percentage of individuals in intervention communities who reported consistent condom use with their main partners increased from $8.5 \%$ at baseline to $17.0 \%$. The percentage using condoms with nonmain partners increased from 25 to $33 \%$. Respondents recently exposed to the intervention were more likely to carry condoms and to have higher "stage-of-change" scores for consistent condom use during vaginal sex and use of bleach to decontaminate injection equipment [67].

The final report from CDC concluded that:

No single intervention can be $100 \%$ effective. The challenge now faced by HIV-prevention researchers and practitioners is to refine and integrate intervention efforts to optimize behavior change. Coordinating community-level interventions in a comprehensive HIV-prevention plan with other, more intensive approaches, such as HIV counseling and testing and group interventions for skill building, may yield greater behavior change. Unless society is willing to address the basic issues that sustain the HIV epidemic, most HIV-prevention programs will achieve only limited success [67, p. 343].

\section{Comprehensive Programs and Mathematical Models}

The inability of biomedical scientists to develop a vaccine and discover a cure for AIDS in the 1980s-and beyondwas preceded by considerable success controlling gonorrhea in the 1970s. Some members of the USPHS who were involved in syphilis eradication efforts in the 1960s and gonorrhea control efforts in the 1970s learned from their experiences and applied the lessons they learned to HIVprevention efforts.

In 1972, CDC's Venereal Disease Control Division (VDCD) became concerned about rising rates of gonorrhea among teenagers and young adults and reports of penicillinase-producing Neisseria gonorrhoeae among servicemen returning to the US from Asia [68]. VDCD launched a National Gonorrhea Control Program (NGCP) consisting of educational communications and enhanced surveillance, screening, and contact tracing. It led to decreases of $74 \%$ in reported gonorrhea rates in the US between 1976 and 1996 [69]. Decreases and subsequent stabilization of gonorrhea rates most likely resulted from changes in behavior; particularly, increases in condom use in response to information about AIDS that was forthcoming in the mid- to late-1980s.

As part of NGCP, pilot operational research projects were established to investigate STIs in Colorado and Ohio [70]. The El Paso County Health Department in Colorado Springs was interested in evaluating classical "venereal disease" testing, patient interviewing, and contact-tracing strategies [71-74] to find and treat cases of gonorrhea in the community and at a near-by military base.

A medical epidemiologist familiar with "the ring strategy" [75] of targeted vaccinations that helped conquer smallpox [76] and other behavioral interventions for interrupting disease transmission [77] served as a liaison and assisted. The research team was well-suited and eager to test implications of a gonorrhea-transmission core-group model [78] in the 1970s and a model of HIV-transmission dynamics when it was proposed in the 1980s [79, 80].

Support for a cross-sectional study of HIV infections in sex workers in 1985-87 (CDC AIDS Project 72) was continued with a cooperative agreement to conduct a prospective study of sociosexual networks of HIV transmission in Colorado Springs in 1988-90 (CDC AIDS Project 90) [81, 82]. The aim was to stop community transmission by: (1) focusing education efforts on high-risk groups, (2) providing continuous outreach in high-risk settings, (3) promoting condom use and safer-sex practices, (4) counseling individuals in civilian and military clinics and local test sites, and (5) conducting assiduous contract tracing, enhanced by ethnographic observations and network analysis [83]. Interviews with 595 Project 90 participants yielded information about the sociosexual relationships of 8759 individuals connected by 31,147 links and the identification of a gigantic component of 7151 people who shared injection equipment or had sexual contact with another.

The prospective study provided insights into network structures of human relationships and how HIV is transmitted in a community $[84,85]$. Leadership by an erudite county health officer and collaboration among an experienced interdisciplinary team that included epidemiologists, social scientists, clinicians, and laboratory technicians produced a comprehensive program of HIV case finding, disease management, and infection control that responded judiciously to the public health needs of the local population [83]. In Colorado Springs, a program of "low tech" interventions designed, administered, and carried out by an enthusiastic, tenacious, well-trained, and experienced team of committed public health workers demonstrated reductions 
of HIV and other STI transmissions in an American community. Despite these results, CDC largely ignored the Colorado Springs study to go in a very different direction after the inauguration of President William Clinton in January 1993.

\section{Community Planning for HIV Prevention}

In December 1993, CDC mandated that all 65 health department grantees receiving cooperative agreements for HIVprevention services (50 states, 8 US territories, 6 major metropolitan areas, and the District of Columbia) involve affected communities and relevant scientific experts in a shared program planning process [86]. The planning process was to follow 7 "necessary steps," recognize 9 "essential components," and observe "13 principles," including prioritizing program activities based on "behavioral theory, population needs, intervention effectiveness and cost-effectiveness, and local values and norms." The 13 principles were drawn from CDC's "Planned Approach to Community Health," a planning model "designed to strengthen state and local health departments' capacities to plan, implement, and evaluate community-based health promotion activities" [87].

Community planning involved thousands of people with diverse backgrounds, interests, and abilities [88]. The approach was established to provide evidence-based and culturally competent programming consistent with community-identified and validated needs, priorities, and values. It sought to maximize participation, inclusion, and representation. Implementation, however, was far from ideal, because community planning groups often lacked the knowledge and skills required to assess and interpret available data, and the resources and competency required to gather additional data needed to make informed decisions about interrupting disease transmission in their communities. Critics of the program-planning process cited Tversky and Kahneman [89] and concluded, "The absence of relevant data can create conditions where personal biases and inappropriate shortcuts can easily occur and adversely affect the quality of decision making" [90].

Many members of community planning groups were good-hearted souls determined to help, but they were not well-qualified or suited to take on the difficult and complex tasks they were asked to do. Evaluations of the first 5 years of community planning showed a smaller percentage of federal dollars allocated to counseling and testing activities and a higher percentage spent on health-education programs targeted at reducing risk of HIV infection [91], but this would soon change. Community planning was doomed to fail because it put "community" ahead of - or at least on a level playing-field with-more powerful players in "the AIDS industry" [92]. As results of randomized control trials (RCTs) of highly active anti-retroviral therapy (HAART) were reported, mortal blows were dealt to community HIV prevention efforts. With evidence that combination antiretroviral therapy (ART) could offset the lethal consequences of HIV infection [93] and, if sustained, could render infected patients noninfectious [94], attention turned to biomedical interventions (especially serologic screening) to find individuals with HIV, and a continuum of HIV care to treat them.

Proven efficacy of ART meant HIV infection was to become more like a chronic disease [93]. Patients would live longer, could resume sexual activities, and, perhaps, become infected and re-infected with a host of STIs [95].

\section{From Mobilization to Medicalization: 2001- 2010}

The second decade of AIDS ushered in the discovery of life-saving antiviral treatment, leading to increased control over HIV-prevention programs by governmental agencies and the decline of influence by behavioral scientists and community activists. Emphasis on using biomedical tools in an expanding toolbox meant that the alphabet soup of abstinence, being faithful, or using a condom for HIV prevention (otherwise known as "ABC") [96] would be replaced by stronger tonics: chemoprophylaxis and treatment as prevention. The third decade saw the continued dissipation of social and behavioral interventions as physicians promoted the uptake of pills for lifetime treatment of HIV infections, pre-exposure prophylaxis, and post-exposure prophylaxis.

\section{Community Mobilization to Eliminate Disparities in HIV Disease}

In 1999, CDC considered HIV to be 1 of 6 chronic diseases affecting racial and ethnic minority populations in the US that required significant attention. The Racial and Ethnic Approaches to Community Health (REACH 2010) program sought to eliminate racial and ethnic disparities in health, a major goal of Healthy People 2010 [97]. The Broward County (Florida) Coalition to Eliminate Disparities in HIV Disease was one of 42 grantees CDC funded to conduct a formative evaluation and develop a community action plan (CAP) in Phase I (1999-2000) and to implement and evaluate the CAP in Phase II (2000-2004). The Broward Coalition consisted of 3 community-based organizations (CBOs), local health department representatives, and public health professionals affiliated with a Hispanic-serving academic institution that served as the central coordinating organization $(\mathrm{CCO})$.

The Broward Coalition adopted the PRECEDE-PROCEED model for community planning and health promotion [98], conducted an extensive needs assessment, and agreed to support 4 interventions to complement ongoing 
HIV-prevention activities in the county [99]. The Coalition chose horizontal outreach to residents, vertical outreach to stakeholders and gatekeepers, strategic communications, and $\mathrm{CBO}$ capacity building and infrastructure development to promote behavioral and social change. CDC officials approved the CAP and awarded a cooperative agreement to the $\mathrm{CCO}$ to implement and evaluate the program over the next 4 years "subject to the availability of funds" (Fig. 3).

During Phase II, increases in awareness, testing, and actions to address AIDS in minority communities were noted in a series of cross-sectional surveys with residents [100]. HIV-incidence rates among the Black population decreased by $60.5 \%$. By the end of the study, HIV incidence rates among Hispanics were the same as among the predominantly White population. Reductions in reported HIV diagnoses were greater among Black residents living in the south Florida media market than in other metropolitan areas of the state. Community mobilization appeared to be a promising strategy for eliminating disparities in HIV disease, but no funds to continue REACH 2010 in south Florida were forthcoming after the demonstration project ended. In fact, the project was severely hampered
Fig. 3 Racial and Ethnic Approaches to Community Health (REACH 2010), Broward County, Florida, 2001-2005: Stay HIV FreeSpoken-word messages from poets residing in priority communities
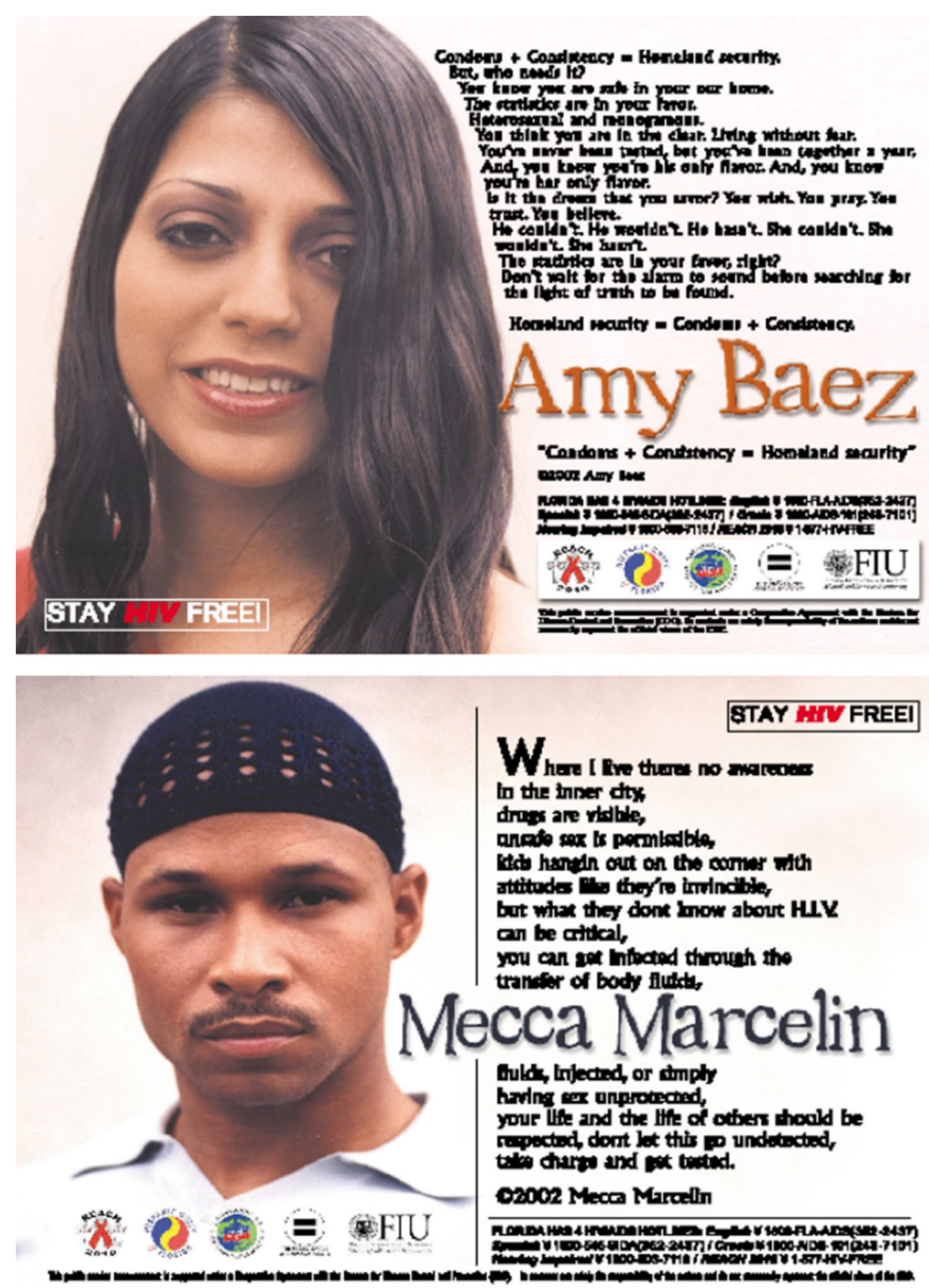
in reaching its goal because CDC cut its annual allocation in half during Year 4 "due to a shortage of funds."

\section{The CDC Synthesis Project: A Portfolio of Options for a Concentrated Epidemic}

The CDC HIV Prevention Research Synthesis (PRS) Project was created in 1996 to identify evidence-based interventions (EBIs) for planning groups and providers to choose and implement those most appropriate for their local programs [101]. PRS relied on meta-analyses of systematic intervention trials to show that behavioral interventions substantially reduced sexual risk among young adults, MSM, heterosexual men and women, and PWID [102]. By 2006, 50 behavioral interventions for high-risk populations met stringent criteria for scientific rigor and efficacy [103]. They were described in a Compendium of Evidence-Based Interventions and Best Practices for HIV Prevention that was first published in 1999 [104]. To facilitate adoption, a dozen efficacious interventions were packaged for use by local programs and training on how to adapt them "with fidelity" was offered through a Diffusion of Effective Behavioral Interventions (DEBI) project launched in March 2002 [105].

With Republican George W. Bush in the White House and Dr. Julie Gerberding serving as Director of CDC, the agency withdrew its support for "homegrown" interventions and required 38 of 50 state health department grantees, 6 cities, Washington, DC, and Puerto Rico to implement interventions CDC had decided could qualify as "evidencebased" [106]. From October 2002 to April 2005, DEBI staff trained 4549 participants from 2001 agencies to use at least one of the 12 packaged interventions in 68 cities throughout 35 states, Puerto Rico, and the Virgin Islands [103]. Critics objected to having the EBIs shoved down their throats through a top-down mode of dissemination that failed to embrace and bolster community concerns and contributions and ignored contextual and critical methodological considerations [107]. Broward Coalition members were furious when their new CDC project officer told them that they would be ineligible for renewed funding because they "had not implemented high-impact interventions." CDC was proud of its massive effort to disseminate efficacious "offthe-shelf" interventions [108-110], but some of their "community partners" were left feeling disrespected, dismayed, and distraught.

\section{The Serostatus Approach, Advancing HIV Prevention, and HIV Prevention for Positives}

The Serostatus Approach to Fighting the Epidemic (SAFE) was created by CDC in response to increases in HIV incidence, a growing population of people living with HIV and AIDS (PLWHA), and the availability of a rapid HIV test
(OraQuick®) [111]. SAFE prioritized those living with HIV and those who were HIV-negative but at high behavioral risk. Objectives were to increase: (1) the number of persons with HIV aware of their serostatus, (2) the use of health care and preventive services, (3) high-quality care and treatment, (4) adherence to HIV therapy, and (5) the number of people with HIV who adopted and sustained safer sexual behaviors.

"Advancing HIV Prevention: New Strategies for a Changing Epidemic" supported SAFE [112]. It advocated the use of four "proven public health approaches" (routine screening, identification of new cases, partner notification, and increased availability of treatment and prevention services) and four priority strategies (making HIV testing a routine part of medical care, diagnosing HIV infections outside medical settings, working with persons diagnosed with HIV and their partners, and further decreasing perinatal HIV transmission). In addition to continuing to support other prevention activities, the new CDC initiative incorporated evaluation in demonstration projects, created national HIV incidence and behavioral surveillance systems, and established new performance indicators for state and local health departments and CBOs. In a major shift in emphasis, CDC announced that it was requiring health departments to make PLWHAs the highest priority for prevention services.

With ART, HIV became a chronic disease requiring lifelong care [93]. In this brave new world of HIV and STI prevention, physicians were called upon to use active listening techniques and talk with (rather than at) their patients [113]. A "Best Practices Guide" developed in 2009 in San Francisco clearly stated that prevention for HIV-positive persons was to be achieved "through HIV education and skills-building interventions, counseling and emotional support, disclosure support, and testing and services for partners of HIV-positive persons" [93]. Behavioral scientists warned that transitioning efforts away from those at risk in a community to those aware of infection should not overlook the principles of positive HIV prevention, relational, and emotional dynamics [114]. Furthermore, screening through a "serologic dragnet" to detect and surveil the more than 250,000 undiagnosed cases in the US must not be done at the expense of proper medical care and respect for human rights [115].

\section{Belittling Behavioral Interventions}

Reviews of behavioral interventions implemented and evaluated from 1985 to 2005 to reduce the risks of HIV infection led some critics to conclude that behavioral interventions were limited with respect to the magnitude of behavior change, ineffective with respect to decreasing HIV incidence, and too costly when compared with more efficacious biomedical and less-expensive structural alternatives [116]. As the standard for "effectiveness" was changed to reflect a 
focus on the biomedical approach, the utility of one-on-one counseling sessions conducted in conjunction with standard and rapid HIV testing came under considerable scrutiny [117]. The counseling model advocated by CDC since 1993 was "client centered" and emphasized interactive communication rather than simply telling a patient what to do [41].

Project RESPECT was a CDC-sponsored RCT conducted between July 1993 and September 1996 at STI clinics in Baltimore, Denver, Newark, Long Beach, and San Francisco. The trial enrolled 5,758 heterosexual, HIV-negative patients to evaluate the efficacy of 2-session and 4-session interactive counseling [118]. Compared with a control condition (didactic teaching), brief interactive counseling resulted in a 30\% reduction in incident STIs at 6 months and a 20\% reduction at 12 months. Results warranted inclusion of Project RESPECT in the first edition of the Compendium of HIV Prevention Interventions with Evidence of Effectiveness [104]. "Booster counseling" was offered as an EBI from 2006 until 2014, when it was "archived" as a result of follow-up studies reporting less-convincing results [119-121].

EXPLORE evaluated "intensive" 10 -session, behaviormodification counseling with 4,295 HIV-negative MSM [122]. After 48 months of observation, EXPLORE resulted in a $18.2 \%$ (95\% CI - 4.7-36.0\%) lower rate of HIV acquisition in those exposed to the intervention compared with standard counseling. Adjustment for baseline covariates attenuated the effect to $15.7 \%$ (95\% CI - 8.4-34.4\%). Investigators argued that intensive counseling for MSM was "plausibly efficacious" and showed that acquired HIV infections were often associated with the use of alcohol or drugs before sex, overall use of amphetamines and heavy alcohol, and unprotected receptive anal intercourse with multiple sexual partners of unknown or presumably HIVnegative serostatus [123]. An analysis of 127 articles that cited results of the EXPLORE study more often judged extensive counseling ineffective (80\%) than effective (20\%), adversely influencing adoption of a "highly effective" way of reducing HIV incidence among MSM [124]. With evidence of a $>35 \%$ reduction in HIV incidence 12 to 18 months after extensive counseling [125], EXPLORE did not qualify as an EBI. It was never included in CDC's updated compendia.

In 2006, CDC reviewed the history of biomedical and behavioral interventions and declared that HIV-prevention programs must evolve to address new challenges [126]. This meant that programs must incorporate biomedical advances in preexposure and postexposure prophylaxis, microbicides, male circumcision, vaccine development, and effects of antiretroviral treatment on infectivity. In addition, programs were to include innovations in HIV-testing technologies and other biomedical breakthroughs.

\section{"Restoring Public Health Principles and Traditions" and PEPFAR}

In 2005, Thomas Frieden, then Commissioner of the New York City Health Department, and colleagues [127] argued that the failure to apply standard disease-control methods undermined society's ability and responsibility to control the HIV epidemic. Now was the time "to adopt traditional diseasecontrol principles and proven interventions that can identify infected persons, interrupt transmission, ensure treatment and case management, and monitor infection and control efforts throughout the population," they contended [127, p. 2397]. Core interventions for the control of communicable disease are prompt diagnosis, systematic partner notification and followup, and accountability for treatment of all patients. "Until we implement prevention programs with proven efficacy more widely, make voluntary screening and linkage to care a normal part of medical care and expand screening in community settings, and improve treatment, risk reduction, monitoring, and partner notification, we will continue to miss opportunities to reduce the spread of HIV infection" [127, p. 2400].

In 2015, Frieden (now Director of CDC) and colleagues [128] presented a progress report and argued: "We must improve immediate reporting, rapid investigation, follow-up, and service to affected persons and communities; use molecular epidemiology to identify chains of transmission that can be interrupted by ART; and screen all adults and adolescents for HIV infection at least once, whether or not clinicians perceive that a patient is at risk, and repeat screening at least annually for people at high risk" [128, p. 2283]. Dr. Frieden and his colleagues had little to say about the role of behavioral and structural interventions in HIV prevention in this or the earlier article about public health principles and traditions.

In 2003, President George W. Bush revealed his administration's President's Emergency Plan for AIDS Relief (PEPFAR) and Congress authorized an $\$ 18$ billion initiative to address HIV and AIDS abroad [129]. It was the largest commitment by any nation for a single disease [130]. In 2008, Congress reauthorized and expanded PEPFAR funding to $\$ 48$ billion [131]. PEPFAR offered resources through bilateral agreements to countries that promised to promote abstinence while domestic HIV-prevention programs were deprived of a much-needed financial boost to fully implement approved activities. AIDS relief overseas looked to some like a diminution of dollars in the US and a curtailment of interest and support for domestic programs. The "thousand points of light" seen by his father, President G. H. W. Bush, faded, and for some-like the Broward Coalition to Eliminate Disparities in HIV Disease-were extinguished for lack of oxygen in the administration of the son, President G. W. Bush. 


\section{Mainstreaming AIDS: 2011-2021}

In March 2010, during the administration of Barack Obama (2009-2017), Congress passed the Patient Care and Affordable Care Act (ACA); it was fully implemented in 2014. The ACA expanded the availability of health insurance, provided more Americans with access to health care, and offered opportunities for improving services to persons living with HIV [132]. It was followed by a National HIV/ AIDS Strategy (NHAS), an HIV-care continuum, and aspirations to end AIDS.

\section{A National Strategy, A Continuum of Care, and The End of AIDS}

The NHAS released by the Obama Administration in July 2010 [133] maintained that "implementation of combination high-impact, HIV-prevention strategies," "data-driven decision making," "integration and consolidation of the continuum of HIV care," and "the reorganization of relationships among public health agencies, researchers, community-based organizations, and HIV advocates" could be used to reduce racial and ethnic health disparities, but the effort would "require multidisciplinary teams...to successfully engage groups at highest risk of HIV and those already infected with HIV" [134, p. 237]. Overall, HIV incidence was to be dramatically reduced through "combination prevention," defined as "the integration of behavioral, biomedical, and structural HIV intervention strategies" and akin in potential to combination antiretroviral therapy [135].

In 2011, the White House Office of National AIDS Policy presented an HIV-care continuum to portray the estimated number of PLWHA receiving the full benefits of the medical care and treatment they needed [136]. The continuum modeled HIV care through 5 distinct and dynamic stages consisting of: (1) diagnosis, (2) linkage to care, (3) retention in care, (4) adherence to antiretroviral therapy, and (5) viral suppression. Data showed the proportion of PLWHA decreased at each successive step of the treatment cascade, beginning with an estimated $86 \%$ who were diagnosed and dropping dramatically to approximately $30 \%$ of PLWHA who were virally suppressed [137]. Interventions were required to improve treatment outcomes [138].

Both the Obama [139] and Trump administrations expressed bold aspirations to exceed goals of 90-90-90 (90\% of all people living with HIV will know their HIV status, $90 \%$ of those diagnosed will be on antiretroviral therapy, and $90 \%$ of those on therapy will achieve viral suppression) [140] and end AIDS [141] by 2030. In 2019, President Donald J. Trump announced his administration's goal to reduce HIV incidence in the US by $75 \%$ within 5 years and $90 \%$ within 10 years [142]. The Trump initiative to end AIDS rested on 4 sturdy pillars: (1) diagnose all individuals with HIV as early as possible after infection, (2) treat HIV infection rapidly and effectively to achieve sustained viral suppression, (3) prevent at-risk individuals from acquiring HIV infection (by expanding the use PrEP), and (4) rapidly detect and respond to emerging clusters of HIV infection to further reduce new transmissions.

\section{Test and Treat}

Mathematical models suggested that the effective use of antiretroviral therapy could control the spread of HIV if all five steps in the HIV-care continuum were to be achieved [143]. A study by the HIV Prevention Trials Network (HPTN 065) conducted between September 2010 and December 2014 in the Bronx borough of New York City and in Washington, DC, was designed to determine the feasibility of the "test and treat" strategy in the US [144]. Chicago, Houston, Miami, and Philadelphia were chosen as "nonintervention comparison sites" in the 3-year "Test, Link-to-Care, plus Treatment" (TLC-Plus) study [145].

Compared with the 3 years before (2008-2010), diagnoses of new HIV infections annually reported to CDC declined by $13.3 \%$ in New York City and by $20.2 \%$ in Washington, DC, during the 3 years that TLC-Plus interventions were implemented (2011-2013), and by $14.8 \%$ in New York and by $20.0 \%$ in DC in the 3 years after (2014-2016). Diagnoses of new HIV infections in the nonintervention comparison sites fell by $13.5 \%$ during and by $9.2 \%$ after TLC-Plus, compared with $15.5 \%$ and $16.3 \%$ for the two intervention cities combined. Six other high HIV-prevalence urban areas saw new HIV diagnoses fall by $5.7 \%$ during and by $0.5 \%$ after these same 3-year periods (Table 1).

New York City [146] and Washington, DC, [147] were having difficulty controlling the spread of HIV before NIH stepped in and generously supported efforts to find people living with HIV, link them to care, and treat them with ART [148]. Stepped-up screening [149] and related activities were associated with reported declines in new HIV infections in the Bronx and DC, but declines were also noted in nonintervention comparison sites and, to a lesser extent, other "hot spots." Effects attributable to the influx of funds and expertise for TLC-Plus were difficult to disentangle from effects attributable to other efforts simultaneously employed to reduce HIV incidence in selected areas of the US $[150,151]$.

\section{Enhanced Comprehensive HIV Prevention Programs}

In collaboration with NIH and others, CDC introduced the Enhanced Comprehensive HIV Prevention Planning (ECHPP) Project to better target resources, meet NHAS goals, and increase local impact [152]. From September 


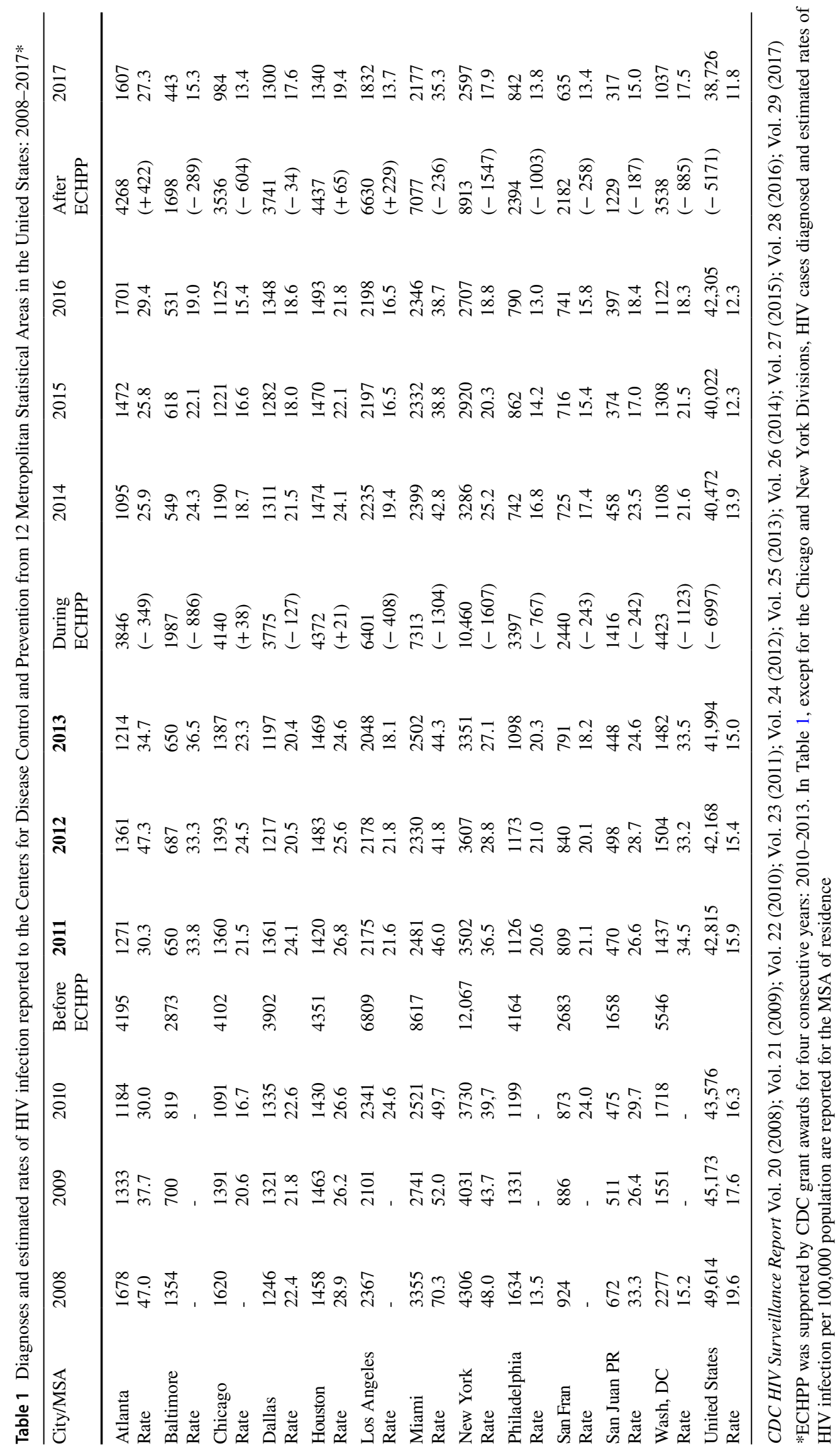


2010 to September 2013, CDC divided \$42.8 million for enhanced prevention planning, coordination, and partial implementation among 12 grantees [153]. Each grantee could include up to 24 interventions; 14 were required and 10 more recommended. Planning was guided by principles laid out by CDC and "situational analysis."

In 2016, Fisher and colleagues [154] conducted a multilevel evaluation spanning multiple years (2008-2015) and using multiple data sources. Initial analysis indicated that the 12 ECHPP grantees increased HIV testing, condom distribution, and partner services, and expanded delivery of prevention programs for PLWHA. Future reports were to assess whether activities specific to ECHPP contributed to changes in client outcomes, and whether client outcomes were associated with changes in community-level impact.

Miami-Dade County (Florida) developed and implemented a locally tailored plan that reinforced local partnerships, identified neighborhoods with highest unmet needs, improved condom distribution, established a new walk-in center for transgender client needs, and resolved incompatibilities in health department and Ryan White Program computer record systems to facilitate more efficient patient services [155]. As a TLC-Plus nonintervention comparison site, the Miami MSA reported $15.1 \%$ fewer newly diagnosed HIV cases during ECHPP and 3.2\% fewer after ECHPP (Table 1). The apparent impact of changes made during the 3 -year ECHPP project were puzzling to several observers who were on the ground during the 2011-2019 administration of Florida Republican “Tea Party” governor, Rick Scott.

"From 2015 to 2017, Florida was forced to return to the federal government \$54 million in unspent grants for combating HIV," according to an article published in the Guardian [156]. In 2015, Scott's administration blocked 2 CDC grant applications that could have won Miami and Broward counties approximately $\$ 16$ million. " 'I think Rick Scott fueled the epidemic in Florida,' said Marlene LaLota, a 28-year veteran of the Florida Department of Health who was the administrator of its HIV/AIDS section from 2014 to 2016."

Despite reductions in newly diagnosed cases of HIV, the Miami Division continued to report in 2019 the highest rate of new HIV infections of any MSA division in the US (42.4 per 100,000) - more than twice the rate reported by New York City (17.7), San Francisco (15.8), and Los Angeles (14.8) [157]. A virologist working at the University of Miami Medical Center was quoted in Science magazine as saying, "We're in a mess. Miami is the epicenter of the epicenter of HIV/AIDS in the United States" [158].
High Impact, A Functional Framework, and Five (or More) D's

To accelerate action to end the HIV epidemic, high-impact HIV prevention, care, treatment, and outbreak response strategies were to be implemented in the US [159]. "High Impact HIV Prevention" was defined as "using scalable interventions with demonstrated potential to reduce new infections in the right populations to yield a major impact on the epidemic" [159, p. 1]. CDC prioritized "highimpact strategies" for funding over behavioral alternatives which the agency deemed less efficacious, because CDCsupported interventions must be "highly effective, scalable, and cost-effective" [159]. However, no behavioral intervention could be deemed "efficacious" if it was never systematically studied and eligible for consideration by CDC's criteria.

In recognition of "landmark advances" and an "evolving landscape," NIH staff proposed in 2017 a functional framework to highlight four major domains for current and future behavioral and social science research (BSSR) on HIV disease [160]. The 4 domains characterized were: (1) understanding vulnerable populations and contexts of risk (Basic BSSR), (2) improving approaches to risk reduction, prevention, and care (Elemental BSSR), (3) strengthening the design of biomedically focused research (Supportive BSSR), and (4) contributing building blocks to integrated prevention and treatment approaches (Integrative BSSR). Integrative BSSR "will advance implementation science at the clinic and community level and will model the best combinations of individual, biomedical, and structural interventions to achieve impact," promised the two authors from NIH [160, p. 379].

With high-impact prevention and a functional framework came recommendations to: (1) de-emphasize differences between HIV and other diseases, (2) destigmatize HIV testing and treatment, (3) decouple HIV counseling from testing, (4) de-implement risk-reduction counseling, and (5) deconstruct the biomedical model that was driving all these changes in HIV-prevention strategies. One of the ways to end AIDS, some thought, was to end "AIDS exceptionalism" and to treat HIV like any other serious, but manageable, disease [161]. By testing everyone between the ages of 16 and 65 at least once, CDC believed it could take the stigma out of HIV testing [117].

Although a 2012 meta-analysis of over 20 studies $(n=52,465)$ concluded that single-session behavioral interventions can have a substantial impact on those counselled (odds ratio $=0.65 ; 95 \%$ CI $0.55-0.77$ ) and rivaled the effects observed for biomedical technologies targeting HIV and STI prevention [162], counseling was declared to be a barrier to testing and was eliminated. Other researchers thought EBIs for promoting behavior change could be 
more effectively accumulated using " ontologies, a systematic method for articulating a 'controlled vocabulary' of agreed-upon terms and their inter-relationships" [163] and research into the antecedents of HIV-risk practices favored a sociological, interpretive, and structural orientation, not a biomedical individualistic orientation. "Thus, with respect to NIH-funded HIV prevention science, there exists a major disjunct in the guiding epistemological orientations of how scientists understand HIV risk, on the one hand, and how they engineer behavior change in behavioral interventions, on the other" [164].

By the 40th anniversary of AIDS, more bad news was being reported. In an RCT of PrEP among gay couples, investigators found "complete indifference" toward STIs among MSM using biomedical prevention [165]. A metaanalysis showed that persons who became aware of their HIV infection were more likely to adopt preventive behaviors and use condoms soon after notification, but this effect diminished and even disappeared over time [166]. And in 2019, 2.5 million cases of chlamydia, gonorrhea, and syphilis were reported to CDC, marking the sixth consecutive year of record-breaking cases of STIs in the US [167].

\section{Program Science, A Macro-level Evaluation, and Healthy Information}

With the shift towards combination HIV-prevention packages and biomedical, behavioral, and structural interventions being implemented concurrently, measuring the overall impact on HIV incidence and the contribution of each component posed significant evaluation challenges [168]. Each package should be sufficiently flexible to include a variety of EBIs that serve each dynamic population they prioritize, particularly those who are most vulnerable [169]. To optimize impact, well-designed implementation science studies are vital. "Efficacy in a clinical trial does not necessarily translate to effectiveness at the population-level," warned Padian and colleagues [169, p. S22]. Studies should investigate programmatic implementation, operations scale-up, and "methods to monitor and evaluate these processes both for organization and cost-effectiveness."

Program Science was introduced in 2011 as "the systematic application of theoretical and empirical scientific knowledge to improve the design, implementation, and evaluation of public health programs" [170]. It proposed an iterative, multi-phase, and interdisciplinary framework whereby programs drive scientific inquiry, and both program and science are aligned towards a collective goal of improving population health [171]. Three spheres in a program cycle included: (1) strategic planning to make informed decisions about program priorities and resource allocation, so the program is aligned with the local epidemic context, (2) program implementation to make informed decisions about 'where,' 'what,' 'how,' and 'for whom' to deliver interventions, and (3) program management and evaluation to generate robust evidence for continuous improvements in program delivery and outcomes. Understanding complexity required consideration of feedback loops, path dependence, phase transitions, compensatory mechanisms, and emergent properties [172].

Combination interventions can produce substantial effects on HIV transmission, as illustrated in an important study reported by our neighbors to the north. In Ontario, Canada, CBOs educated vulnerable populations and communities, developed meaningful relationships through community outreach, and delivered services that accounted for the impact of stigma, culture, and human rights, as well as the social, behavioral, and structural factors that affect HIV risk. Community-based and behavioral interventions were effective in: (1) reducing risky sexual behavior and the incidence of STIs in high-risk populations, (2) increasing condom use, (3) increasing knowledge of HIV transmission and prevention, (4) improving adherence to ART, and (5) improving retention in care and treatment [173]. From 1987 to 2011, province-wide, community-based programs helped to avert an estimated 16,672 HIV infections, saving Ontario's health care system approximately $\$ 6.5$ billion Canadian dollars (range 4.8-7.5B). From 2005 to 2011, every dollar invested in these programs saved about $\$ 5$.

While the US Surgeon General has reason to worry about the circulation of health misinformation in the digital age [174], we can still turn to books [175, 176], review articles (Table 2), and other sources that can teach us about the history of the AIDS pandemic and the significant contributions of so many social, behavioral, and other scientists in finding solutions. Among the more recent contributions with cogent arguments and compelling ideas for improving health-promotion programs are Extra Life [177], People Count [178], and Stuck [179]. Lindsey McGoey [180, 181] published a pair of books well worth reading, and Adam Kucharski reminded us in The Rules of Contagion [182] that the reproduction number, R, still depends on DOTS: (1) duration of infectiousness in a host, (2) opportunities hosts have to spread an infectious agent to others, (3) transmission probabilities, and (4) susceptibility of contacts in a population. We must always keep our eye on the prize-stopping the spread of HIV and other infectious pathogens in vulnerable communities.

\section{Summary}

Like Johnny Appleseed, we have planted, fertilized, and trimmed a variety of trees (developed interventions) over the past 40 years, but we have not paid close attention to growing an entire forest (everything that constitutes viable and ecologically robust HIV-prevention programs). Decisions 
Table 2 Anniversary reviews after 10, 15, 20, 25, 30, and 40 years of the HIV/AIDS pandemic

Anniversary Article, Book, or Online posting

10 Years Centers for Disease Control and Prevention. The HIV/AIDS epidemic: The first 10 years. MMWR 1991;40(22):357.

Grmek MD. History of AIDS: Emergence and Origin of a Modern Pandemic. Princeton, NJ: Princeton University Press; 1993.

15 Years Fauci AS. AIDS in 1996: Much accomplished, much to do. JAMA 1996;276:155-6.

20 Years Brodie M, Hamel E, Brady LA, Kates J, Altman DE. AIDS at 21: Media coverage of the HIV epidemic, 1981-2002, Columbia Journalism Review 2004;Suppl. March/April: A1-8.

Centers for Disease Control and Prevention. Twenty Years of AIDS [Video]. Available at: https://www.youtube.com/watch?v= LabdrWmUN4w\%26t=242s.

Gottlieb MS. AIDS: Past, present, and future. N Engl J Med. 2001;344(23):1788-91.

Sepkowitz KA, AIDS—The first 20 years. N Engl J Med. 2001;344(23):1764-72. https://doi.org/10.1056/NEJM200106073442306

Steinbrook R, Drazen JM. AIDS—Will the next 20 years be different? N Engl J Med. 2001;44 (23):1781-2. https://doi.org/10. 1056/NEJM200106073442308.

25 Years Centers for Disease Control and Prevention. Twenty-five years of HIV/AIDS—United States, 1981-2006. Morb Mort Wkly Rep (MMWR). 2006;55(21):585-9.

Fauci AS. 25 years of HIV. Nature. 2008;453(7193):289-90. https://doi.org/10.1038/453289a.

Greene WC. A history of AIDS: Looking back to see ahead. Eur J Immunolo. 2007;37:S94-102.

Kalichman SC. Time to take stock in HIV/AIDS prevention. AIDS Behav. 2008;12(3):333-4. https://doi.org/10.1007/s10461-0089377-1.

30 Years Alcorn K. 30 years of AIDS: Remembering how it began-from those who were there. NAM AIDSmap. 2011 (June 3). Available at: https://www.aidsmap.com/news/jun-2011/30-years-aids-remembering-how-it-began-those-who-were-there.

Cisneros L. Thirty years of AIDS: A timeline of the epidemic. Patient Care. 2011 (June 6). Available at: https://www.ucsf.edu/ news/2011/06/104134/thirty-years-aids-timeline-epidemic.

DeCock KM, Jaffe HW, Curran JW. Reflections on 30 years of AIDS. Emer Inf Dis. 2011;17(6):1044-8.

Harden VA. AIDS at 30: A History. Dulles, VA: Potomac, 2012.

Valdiserri RO. Thirty years of AIDS in America: A story of infinite hope. AIDS Educ Prev. 2011;23(6):479-94. https://doi.org/10. 1521/aeap.2011.23.6.479 22,201,233

40 Years Beyrer C. A pandemic anniversary: 40 years of HIV/AIDS. Lancet. 2021;397(10,290):2142-3. https://doi.org/10.1016/S01406736(21)01167-3

Cisneros L. 40 Years of AIDS: A timeline of the epidemic. Patient Care. 2021 (June 4). Available at: https://www.ucsf.edu/news/ 2021/06/420686/40-years-aids-timeline-epidemic

El-Sadr WM. Beyond the magic bullet: What will It take to end the AIDS epidemic? Am J Public Health. 2021;111(7):1234-6. doi.org/10.2105/AJPH.2021.306290

Fauci AS, Lane HC. Four decades of HIV/AIDS—Much accomplished, much to do. N Engl J Med. 2020;383(1):1-4. https://doi. org/10.1056/NEJMp1916753

Forty years of HIV/AIDS: A painful anniversary. Lancet. 2021;397(10290):2125. https://doi.org/10.1016/S0140-6736(21)01213-7

Purcell DW. Forty years of HIV: The intersection of laws, stigma, and sexual behavior and identity. Am J Public Health. 2021;111(7):1231-3. https://doi.org/10.2105/AJPH.2021.306335

have bounced in different directions because of competing concerns about constituents, priorities, and influential interest groups. Decision makers have not been able to steer a steady course of choosing what is most important for the public's health.

Priorities over the past 40 years sometimes favored communities-places where people live, work, and play. At other times, they have favored clinics-places where health care providers see patients and practice medicine. Primary objects of concern sometimes favored addressing behaviors associated with reducing risks of HIV transmission and other times focused on helping PLWH to achieve undetectable viral loads. A public health focus on people who engaged in "protected" or "condomless" sexual activities with others was to be replaced instead by a focus on pills and adherence to medications. A major interest in primary prevention was undermined by competing interests in secondary and tertiary prevention. Stages of behavior change were superseded by steps in an HIV-care continuum. Tools for the biomedical tool kit, strategies, and activities competed for resources with tailored, integrated, and efficiently operating programs. As the measure of "success," efficacy was preferred to effectiveness. Strategic plans-with expectations of automatic 5-year renewal or of planned obsolescence-were preferred to rigorous evaluation and reform, with the optimal blend of program activities and services tied to reliable metrics of declining HIV and STI incidence. Participation, inclusion, and representation were displaced by guidance, capacity building, and technical assistance. Programs that "advance HIV prevention through research synthesis" were 
funded while programs that interrupted HIV transmission in vulnerable communities were not. Propaganda, slogans, and bureaucratic bullying seemed at times to be more important than sustained efforts, progress, and realized outcomes.

Tulchinsky and Varavikova [183, p. 49] noted in their 2009 book about contemporary public health: "The interactions among community public health, personal health services, and health-related behavior, including their management, are the essence of the New Public Health." When federal agencies dictate to grantees how funds must be spent to control HIV transmission in local communities, there is no meaningful interaction and there is no "public" health. Effective HIV-prevention programs arise from interdisciplinary collaboration, interagency cooperation, and careful consideration of all of the evidence [184].

\section{Conclusion}

The most important lesson to learn from the first 40 years of AIDS is that the ship of HIV prevention has too frequently been blown off course. Early on, a mathematical model suggested that we should focus our HIV-prevention efforts on $\mathrm{R}_{0}$. But too many admirals and too many deckhands have had too many different ideas about where the ship should be heading. They may have agreed that the final destination was to end AIDS, but they could not agree on how to get there.

In the end, all HIV-prevention programs must be implemented at the local level-in vulnerable communities and with people who live there. Success in the next 40 years will depend on the quality of HIV-prevention programs that are created for diverse ecological environments and susceptible populations, fully implemented and continually improved by well-trained and enthusiastic public health workers, and supported by community members who are invested in, contribute to, and benefit from potent, synchronized, and appropriately delivered interventions.

\begin{abstract}
Acknowledgements Reviewers who provided me with many constructive comments and extremely helpful suggestions included: A. Paige Baker, former Executive Editor, HIV.gov; David W. Forrest, Ph.D., Department of Anthropology, University of Miami, USA; and Richard A. McKay, DPhil, Department of History and Philosophy of Science, University of Cambridge, UK. Thanks also to Fred Fejes, PhD, Professor Emeritus, Florida Atlantic University, and Ms. Althea "Vicki" Silvera, Head of the Special Collections Department, and Barbara M. Sorondo, PhD, Health Sciences Librarian, Florida International University, who helped me obtain and review historical documents and archival materials. Ms. Vicky Vazquez, NIH National Research Service Award Fellow with the Robert Stempel College of Public Health and Social Work, translated the abstract from English into Spanish.
\end{abstract}

Author Contribution The author is solely responsible for the opinions expressed in this article.
Funding The author was not compensated for this work.

Data Availability Not applicable.

\section{Declarations}

Conflict of interest The author has no financial or non-financial interests to disclose.

Ethical Approval Not applicable.

Consent to Participate Not applicable.

Consent for Publication Not applicable.

Code Availability Not applicable.

\section{References}

1. Gottlieb MS. Discovering AIDS. Epidemiology. 1998;9(4):365-7.

2. Siegal FP, Siegal M. AIDS, The medical mystery. New York: Grove Press; 1983.

3. Fettner AG, Check WA. The truth about AIDS: evolution of an epidemic. New York: Holt, Rinehart and Winston; 1984.

4. Bartholomew Eldridge LK, Markham CM, Ruiter RAD, Fernández ME, Kok G, Parcel GS. Planning health promotion programs: an intervention mapping approach. 4th ed. San Francisco, CA: Jossey-Bass; 2016.

5. Brownson RC, Fielding JE, Maylahn CM. Evidence-based public health: a fundamental concept for public health practice. Ann Rev Public Health. 2009;30:175-201. https://doi.org/10.1146/ annurev.publhealth.031308.100134.

6. Green LW, Kreuter MW. Health promotion planning: an educational and ecological approach. 4th ed. New York: McGraw-Hill; 2005.

7. Darrow WW. A national HIV prevention strategy for the United States. In: Smith RA. editor. Politics and government. Santa Barbara, CA: Praeger; 2013:225-48. Smith RA, ediotr. Global HIV/ AIDS Politics, policy, and activism: persistent challenges and emerging issues; vol. 1.

8. Darrow WW. Community mobilization, community planning, and community-based research for HIV prevention in the United States. In: Smith RA, editor. Activism and Community Mobilization. Santa Barbara, CA: Praeger; 2013:375-99. Smith RA, editor. Global HIV/AIDS Politics, Policy, and Activism: Persistent Challenges and Emerging Issues; vol. 3.

9. Pepin J. The origins of AIDS. Cambridge, UK: Cambridge University Press; 2011.

10. Barré-Sinoussi F, Chermann JC, Rey F, et al. Isolation of a T-lymphotropic retrovirus from a patient at risk for acquired immunodeficiency syndrome (AIDS). Science. 1983;220:868-71.

11. IARC Working Group on the Evaluation of Carcinogenic Risks to Humans. Human immunodeficiency viruses and human T-cell lymphotropic viruses. Lyon, FR: international agency for research on cancer; 1996.

12. Gilbert MTP, Rambaut A, Wlasiuk G, Spira TJ, Pitchenik AE, Worobey M. The emergence of HIV/AIDS in the Americas and beyond. Proc Natl Acad Sci USA. 2007;104(47):18566-70.

13. Worobey M, Watts TD, McKay RA, et al. 1970s and "Patient 0" HIV-1 genomes illuminate early HIV/AIDS history in North America. Nature. 2016;539(7627):98-101. 
14. Des Jarlais DC, Friedman SR, Novick DM, et al. HIV-1 infection among intravenous drug users in Manhattan, New York City, from 1977 through 1987. JAMA. 1989;261(7):1008-12. https:// doi.org/10.1001/jama.261.7.1008.

15. Mass L. Disease rumors largely unfounded. New York Native, May 18-31. 1981;7.

16. Centers for Disease Control and Prevention. Pneumocystis pneumonia-Los Angeles. MMWR Morb Mortal Wkly Rep. 1981;30:2-3.

17. Centers for Disease Control and Prevention. Kaposi's sarcoma and pneumocystis pneumonia among homosexual men-New York City and California. MMWR Morb Mortal Wkly Rep. 1981;30:305-8.

18. Altman LK. Rare cancer seen in 41 homosexuals. New York Times, July 3. 1981;A20.

19. Shilts R. And the band played on: politics, people, and the AIDS epidemic. New York: St. Martin's Press; 1987.

20. O'Shea M, Malsbury S, Mennerich D, Stinson J. Gay men's health crisis records. New York: New York public library, humanities and social sciences library, manuscripts and archives division; 2010.

21. Bausum A. Viral: the fight against AIDS in America. New York: Viking; 2019.

22. Kayal PM. Bearing witness: Gay men's health crisis and the politics of AIDS. Boulder, CO: Westview; 1993.

23. Berkowitz R, Callen M. How to have sex in an epidemic: one approach. New York: News from the Front Publications; 1983.

24. Stevens CE, Taylor PE, Zang EA, et al. Human T-cell lymphotropic virus type III infection in a cohort of homosexual men in New York City. JAMA. 1986;255:2167-72.

25. France D. How to survive a plague: the inside story of how citizens and science tamed AIDS. New York: Knopf; 2016.

26. Rogers EM, Dearing JW, Rao N, et al. Communication and community in a city under siege: the AIDS epidemic in San Francisco. Communic Res. 1995;22(6):664-78. https://doi.org/10. $1177 / 009365095022006005$.

27. Sisters of Perpetual Indulgence. Play Fair! San Francisco, CA: The Sisters. 1982. http://s3-us-west-2.amazonaws.com/ucldcnuxeo-ref-media/5cafc7e3-63d2-4e35-be05-1 cab00b065c0. Accessed 9 August, 2021.

28. Hughes SS. Marcus Conant MD, Founding the KS clinic, and continued AIDS activism: an oral history conducted in 1992 and 1995. The AIDS Epidemic in San Francisco: The Medical Response, 1981-1984, Volume II. Berkeley, CA: Regional Oral History Office, The Bancroft Library, University of California, Berkeley; 1996. http://content.cdlib.org/view?docId=kt7b6 9n8jn;NAAN=13030\&doc.view $=$ frames \& chunk.id=d0e4279\& toc.depth=1\&toc.id=d0e4279\&brand=calisphere. Accessed 30 September, 2021.

29. Wohlfeiler D. Community organizing and community building among gay and bisexual men: the Stop AIDS Project. In: Minkler $\mathrm{M}$, editor. Community organizing and community building in health. New Brunswick, NJ: Rutgers University Press; 1998. p. 230-43.

30. Puckett SB, Bye LL. The STOP AIDS project: an interpersonal AIDS-prevention program. San Francisco, CA: STOP AIDS Project; 1987.

31. Winkelstein W Jr, Wiley JA, Padian NS, et al. The San Francisco men's health study: continued decline in HIV seroconversion rates among homosexual/bisexual men. Am J Public Health. 1988;78(11):1472-4. https://doi.org/10.2105/ajph.78.11.147.

32. Samuel M, Hessol N, Shiboski S, Engel RR, Speed TP, Winkelstein W. Factors associated with human immunodeficiency virus seroconversion in three San Francisco cohort studies, 1984-9. JAIDS. 1993;6:303-12.
33. Bye LL. Moving beyond counseling and knowledge-enhancing interventions: a plea for community-level AIDS prevention strategies. In: Ostrow DG, editor. Behavioral Aspects of AIDS. Boston, MA: Springer; 1990:157-67. https://doi.org/10.1007/ 978-1-4757-9386-4.

34. Petrow S, Franks P, Wolfred TR, editors. Ending the HIV epidemic: community strategies in disease prevention and health promotion. Santa Cruz, CA: Network Publications; 1990.

35. Catania JA, Kegeles SM, Coates TJ. Towards an understanding of risk behavior: an AIDS risk reduction model (ARRM). Health Educ Q. 1990;17(1):53-72. https://doi.org/10.1177/1090198190 01700107.

36. Kegeles SM, Hays RB, Coates TJ. The Mpowerment Project: a community-level HIV prevention intervention for young gay men. Am J Public Health. 1996;86(8):1129-36. https://doi.org/ 10.2105/ajph.86.8_pt_1.1129.

37. Jaffe HW, Choi K, Thomas PA, et al. National case-control study of Kaposi's sarcoma and pneumocystis carinii pneumonia in homosexual men: Part 1. Epidemiologic results. Ann Intern Med. 1983;99(2):145-51. https://doi.org/10.7326/ 0003-4819-99-2-145.

38. Curran JW, Jaffe HW. AIDS: the early years and CDC's response. MMWR Morb Mortal Wkly Rep. 2011;60(4):64-9.

39. Centers for Disease Control and Prevention. Prevention of acquired immune deficiency syndrome (AIDS): report of interagency recommendations. MMWR Morb Mortal Wkly Rep. 1983;32:101-3.

40. Gallo R. Virus hunting: AIDS, cancer, and the human retrovirus: the story of scientific discovery. New York: Basic Books; 1991.

41. Centers for Disease Control and Prevention (CDC). HIV counseling, testing and referral standards and guidelines. Atlanta, GA: CDC; 1994.

42. Public Health Service plan for the prevention and control of acquired immune deficiency syndrome (AIDS). Public Health Rep. 1985;100(5):453-5. https://stacks.cdc.gov/view/cdc/66253. Accessed 26 Sep 2021.

43. Coolfont report: a PHS plan for prevention and control of AIDS and the AIDS virus. Public Health Rep. 1986;101(4):341-8. https://pubmed.ncbi.nlm.nih.gov/3016789/. Accessed 26 Sept 2021.

44. Report of the second public health service conference on AIDS. Public Health Rep. 1988;103(suppl):1-109. http://www.ncbi. nlm.nih.gov/pmc/articles/PMC1477921/pdf/pubhealthrep001 66-0002.pdf. Accessed 30 Sep 2021.

45. Koop CE. Surgeon general's report on acquired immune deficiency syndrome. Washington, DC: US Department of Health and Human Services; 1986. https://profiles.nlm.nih.gov/spotl ight/nn/catalog/nlm:nlmuid-101584932X347-doc. Accessed 29 Sep 2021

46. Woods DR, Davis D, Westover BJ. "America responds to AIDS:" its content, development process, and outcome. Public Health Rep. 1991;106(6):616-22.

47. Keiser NH. Strategies of media marketing for "America Responds to AIDS" and applying lessons learned. Public Health Rep. 1991;106(6):623-7.

48. Schwartz B. America responds to AIDS. In: Social marketing: views from inside the government. Washington, DC: Academy for Educational Development; 1991:30-5.

49. Mason JO, Noble GR, Lindsey BK, et al. Current CDC efforts to prevent and control human immunodeficiency virus infection and AIDS in the United States through information and education. Public Health Rep. 1988;103:255-63.

50. Fineberg HV. Education to prevent AIDS: prospects and obstacles. Science. 1988;239(4840):592-6. https://doi.org/10.1126/ science. 3340845 . 
51. The presidential commission on the human immunodeficiency virus epidemic report. Washington, DC: US Government Printing Office; 1988 [Document 0-214-701:OL3].

52. Gebbie KM. The president's commission on AIDS: what did it do? Am J Public Health. 1989;79(7):868-70. https://doi.org/10. 2105/ajph.79.7.868.

53. Centers for Disease Control and Prevention. The HIV/AIDS epidemic: the first 10 years. MMWR Morb Mortal Wkly Rep. 1991;40(22):357.

54. Kelly JA, St Lawrence JS, Diaz YE, et al. HIV risk behavior reduction following intervention with key opinion leaders of population: an experimental analysis. Am J Public Health. 1991;81(2):168-71. https://doi.org/10.2105/ajph.81.2.168.

55. Kelly JA, St. Lawrence S, Stevenson LY, et al. Community AIDS/HIV risk reduction: the effects of endorsements by popular people in three cities. Am J Public Health. 1992;82(11):1483-9. https://doi.org/10.2105/ajph.82.11.1483.

56. Kelly JA, Murphy DA, Sikkema KJ, et al. Randomised, controlled, community-level HIV-prevention intervention for sexual-risk behaviour among homosexual men in US cities: community HIV Prevention Research Collaborative. Lancet. 1997;350(9090):1500-5. https://doi.org/10.1016/s01406736(97)07439-4.

57. Szalavitz M. Undoing drugs: the untold story of harm reduction and the future of addiction. New York: Hachette; 2021.

58. Vlahov D, Junge B. The role of needle exchange programs in HIV prevention. Public Health Rep. 1998;113(Suppl 1):75-80.

59. Heimer R. Community coverage and HIV prevention: assessing metrics for estimating HIV incidence through syringe exchange. Int J Drug Policy. 2008;19(Suppl 1):S65-73. https:// doi.org/10.1016/j.drugpo.2007.12.004.

60. Strike C, Miskovic M. Scoping out the literature on mobile needle and syringe programs-review of service delivery and client characteristics, operation, utilization, referrals, and impact. Harm Reduct J. 2018;15(1):6.

61. Des Jarlais DC. Evaluating national harm reduction programs. Addiction. 2005;100:1575-6. https://doi.org/10.1111/j.13600443.2005.01281.x.

62. Des Jarlais DC, Perlis T, Arasteh K, et al. HIV incidence among injection drug users in New York City, 1990 to 2002: Use of serologic test algorithm to assess expansion of HIV prevention services. Am J Public Health. 2005;95(8):1439-44. https://doi.org/10.2105/AJPH.2003.036517.

63. Des Jarlais DC, Friedman SR, Sotheran JL, et al. Continuity and change within an HIV epidemic: injecting drug users in New York City, 1984 through 1992. JAMA. 1994;271(2):121-7.

64. Des Jarlais DC. Harm reduction in the USA: the research perspective and an archive to David Purchase. Harm Reduct J. 2017. https://doi.org/10.1186/s12954-017-0178-6.

65. O'Reilly K, Higgins D. AIDS community demonstration projects for HIV prevention among hard-to-reach groups. Public Health Rep. 1991;106:714-20.

66. Centers for Disease Control and Prevention. Community-level prevention of human immunodeficiency virus infection among high-risk populations: the AIDS Community Demonstration Projects. MMWR Morb Mortal Wkly Rep. 1996;45(RR-6):1-16.

67. CDC AIDS Community Demonstration Project Research Group. Community-level HIV intervention in 5 cities: final outcome data from the CDC AIDS community demonstration projects. Am J Public Health. 1999;89:336-45. https://doi.org/10.2105/ajph. 89.3.336.

68. Henderson RH. Venereal disease: a national health problem. Clin Obstet Gynecol. 1975;18(1):223-32. https://doi.org/10.1097/ 00003081-197503000-00019.
69. Peterman TA, O'Connor K, Bradley HM, Torrone EA, Bernstein KT. Gonorrhea control, United States, 1972-2015, a narrative review. Sex Transm Dis. 2016;43(12):725-30. https://doi.org/ 10.1097/OLQ.0000000000000515.

70. Rothenberg RB, Judson FN, Maltz A. Strategic planning system for venereal disease control. Sex Transm Dis. 1979;6:1-4.

71. Parran T. Shadow on the Land: Syphilis. New York: Reynal \& Hitchcock; 1937.

72. Parran T, Vonderlehr RA. Plain words about venereal disease. New York: Reynal \& Hitchcock; 1941.

73. Vonderlehr RA, Heller JR Jr. The control of venereal disease. New York: Reynal \& Hitchcock; 1946.

74. US Department of health, education, and welfare. Syphilis: modern diagnosis and management. Washington, DC: Public Health Service Publication Number 743. US Government Printing Office; 1961.

75. Foege WH, Millar JD, Lane JM. Selective epidemiologic control in smallpox eradication. Am J Epidemiol. 1971;94(4):311-5. https://doi.org/10.1093/oxfordjournals.aje.a121325.

76. Foege WH. House on fire: the fight to eradicate smallpox. Oakland, CA: University of California Press; 2012.

77. Garrett L. The coming plague: newly emerging diseases in a world out of balance. New York: Farrar, Straus and Giroux; 1994.

78. Yorke JA, Hethcote HW, Nold A. Dynamics and control of the transmission of gonorrhea. Sex Transm Dis. 1978;5:51-6.

79. May RM, Anderson RM. Transmission dynamics of HIV infection. Nature. 1987;18;326(6109):137-142. https://doi.org/10. 1038/326137a0

80. Anderson RM, May RM. Infectious diseases of humans: dynamics and control. Oxford: Oxford University Press; 1991.

81. Klovdahl AS. Social networks and the spread of infectious diseases: the AIDS example. Soc Sci Med. 1985;21(11):1203-16. https://doi.org/10.1016/0277-9536(85)90269-2.

82. Klovdahl A, Potterat J, Woodhouse D, Muth J, Muth S, Darrow W. Social networks and infectious disease: the Colorado Springs Study. Soc Sci Med. 1994;38(1):79-88. https://doi.org/10.1016/ 0277-9536(94)90302-6.

83. Potterat JJ. Seeking the Positives: a life spent on the cutting edge of public health. North Charleston, SC: CreateSpace; 2015.

84. Potterat JJ, Phillips-Plummer L, Muth SQ, et al. Risk network structure in the early epidemic phase of HIV transmission in Colorado Springs. Sex Transm Inf. 2002;78:159-63.

85. Potterat JJ, Woodhouse DE, Muth SQ, et al. Network dynamism: history and lessons of the Colorado Springs study. In: Morris M, editor., et al., Network Epidemiology: A Handbook of Network Survey Design. London: Oxford University Press; 2004. p. 87-114.

86. Valdiserri RO, Aultman TV, Curran JW. Community planning: a national strategy to improve HIV prevention programs. J Community Health. 1995;20(2):87-100. https://doi.org/10.1007/ BF02260331.

87. Green LW, Kreuter MW. CDC's planned approach to community health as an application of PRECEED and an inspiration for PROCEED. J Health Educ. 1992;23:140-3.

88. Dearing JW, Larson RS, Randall LM, Pope RS. Local reinvention of the CDC HIV prevention community planning initiative. J Community Health. 1998;23(2):113-26. https://doi.org/10. 1023/a:1018709423879.

89. Tversky A, Kahneman D. Judgment under uncertainty: heuristics and biases. Science. 1974;185(4157):1124-31. https://doi.org/10. 1126/science.185.4157.1124.

90. Jenkins RA, Averbach AR, Robbins A, et al. Improving the use of data for HIV prevention decision making: lessons learned. AIDS Behav. 2005;9(Suppl 2):S87-99. https://doi.org/10.1007/ s10461-005-3947-8. 
91. Johnson-Masotti AP, Pinkerton SD, Holtgrave DR, et al. Decision-making in HIV prevention community planning: an integrative review. J Community Health. 2000;25:95-112. https://doi. org/10.1023/A:1005125506642.

92. Altman D. Globalization and the "AIDS industry." Contemp Polit. 1998;4(3):233-45. https://doi.org/10.1080/1356977980 8449965.

93. HIV-CAUSAL Collaboration, Ray M, Logan R, et al. The effect of combined antiretroviral therapy on the overall mortality of HIV-infected individuals. AIDS. 2010;24(1):123-137. https:// doi.org/10.1097/QAD.0b013e3283324283.

94. Cohen MS. Preventing sexual transmission of HIV. Clin Infect Dis. 2007;45(Suppl 4):S287-92. https://doi.org/10.1086/522552.

95. Prevention with Positives Workgroup, HIV Prevention Planning Council. Prevention with Positives: Best Practices Guide. San Francisco, CA: Harder+Company Community Research; 2009. http://www.sfhivcare.com/PDFs/prevention_with_positives_ best_practices_guide.pdf. Accessed 22 Aug 2021.

96. Collins C, Coates TJ, Curran J. Moving beyond the alphabet soup of HIV prevention. AIDS. 2008;(Suppl 2):S5-8. https://doi.org/ 10.1097/01.aids.0000327431.82795.49.

97. Giles WH, Tucker P, Brown L, et al. Racial and ethnic approaches to community health (REACH 2010): an overview. Ethn Dis. 2004;14(3)(Suppl 1):S5-8.

98. Green LW, Kreuter MW. Health Promotion Planning: An Educational and Ecological Approach. 3rd ed. Mountain View, CA: Mayfield; 1999.

99. Darrow WW, Montanea JE, Fernández PB, Zucker UF, Stephens DP, Gladwin H. Eliminating disparities in HIV disease: community mobilization to prevent HIV transmission among Black and Hispanic young adults in Broward County, Florida. Ethn Dis. 2004;14(3)(Suppl 1):S108-16.

100. Darrow WW, Kim S, Montanea JE, Uribe CL, Sánchez-Braña E, Gladwin H. Summative evaluation of a community mobilization program to eliminate racial and ethnic disparities in HIV disease. Int Public Health J. 2010;2:301-11.

101. Doll LS, Holtgrave DR. The HIV/AIDS prevention research synthesis project: implications for federal HIV prevention policy. J Acquir Immune Defic Syndr. 2002;30(Suppl 1):S130-3. https:// doi.org/10.1097/00042560-200207011-00012.

102. Sogolow E, Peersman G, Semaan S, Strouse D, Lyles CM, HIV/ AIDS Prevention research synthesis project team. The HIV/ AIDS prevention research synthesis project: scope, methods, and study classification results. J Acquir Immune Defic Syndr. 2002;30(Suppl 1):S15-29. https://doi.org/10.1097/00042560200207011-00003

103. Lyles C, Crepaz N, Herbst JH, Kay LS, HIV/AIDS Prevention Research Synthesis Team. Evidence-based HIV behavioral prevention from the perspective of CDC's HIV/AIDS prevention research synthesis team. AIDS Educ Prev. 2006;18(Suppl A):21-31.

104. Centers for Disease Control and Prevention (CDC). Compendium of HIV prevention interventions with evidence of effectiveness. Atlanta, GA: CDC; 1999 (Revised 2001). https://web.archive. org/web/20030308025520/http://www.cdc.gov/hiv/pubs/HIVco mpendium/hivcompendium.pdf. Accessed 30 Sep 2021.

105. Collins C, Harshbarger C, Sawyer R, Hamdallah M. The diffusion of effective behavioral interventions project: development, implementation, and lessons learned. AIDS Educ Prev. 2006;18(4) (Suppl A):5-20. https://doi.org/10.1521/aeap.2006.18.supp.5.

106. McKleroy VS, Galbraith JS, Cummings B, et al. Adapting evidence-based behavioral interventions for new settings and target populations. AIDS Educ Prev. 2006;18(4)(Suppl A):59-73. https://doi.org/10.1521/aeap.2006.18.supp.59.

107. Dworkin SL, Pinto RM, Hunter J, Rapkin B, Remien RH. Keeping the spirit of community partnerships alive in the scale up of
HIV/AIDS prevention: critical reflections on the roll out of DEBI (Diffusion of Effective Behavioral Interventions). Am J Community Psychol. 2008;42(1-2):51-9. https://doi.org/10.1007/ s10464-008-9183-y.

108. Collins CB Jr, Sapiano TN. Lessons learned from dissemination of evidence-based interventions for HIV prevention. Am J Prev Med. 2016;51(4)(Suppl 2):S140-7. https://doi.org/10.1016/j. amepre.2016.05.017.

109. Koenig LJ, Lyles CM, Higa D, Mullins MM, Sipe TA. Research synthesis, HIV prevention response, and public health: CDC's HIV/AIDS Prevention Research Synthesis Project. Public Health Rep. 2021. https://doi.org/10.1177/0033354920988871.

110. Williams WO, Uhl G, Eke A, et al. CDC's communitybased organization behavioral outcomes project: perspectives for researchers, implementers and funders. AIDS Behav. 2021;1:284-93. https://doi.org/10.1007/s10461-020-02970-7.

111. Janssen RS, Holtgrave DR, Valdiserri RO, Shepherd M, Gayle HD. The serostatus approach to fighting the HIV epidemic: prevention strategies for infected individuals. Am J Public Health. 2001;91:1019-24.

112. Centers for Disease Control and Prevention. Advancing HIV prevention: new strategies for a changing epidemic-United States, 2003. MMWR Morb Mortal Wkly Rep. 2003;52:329-32.

113. Rietmeijer CA. Risk reduction counseling for prevention of sexually transmitted infections: how it works and how to make it work. Sex Transm Infect. 2007;83(1):2-9. https://doi.org/10. 1136/sti.2006.017319.

114. Auerbach JD. Principles of positive prevention. J Acquir Immune Defic Syndr. 2004;7(Suppl 2):S122-5.

115. Mann JM. Medicine and public health, ethics, and human rights. In: Mann JM, Gruskin S, Grodin MA, Annas GJ, editors. Health and human rights: A Reader. New York: Routledge; 1999. p. $216-26$.

116. Wohlfeiler D, Ellen JM. The limits of behavioral interventions for HIV prevention. In: Cohen L, Chávez V, Chehimi S, editors. Prevention is Primary: strategies for community well-being. 2nd ed. San Francisco, CA: Jossey-Bass; 2010. p. 352-70.

117. Johns DM, Bayer R, Fairchild AL. Evidence and the politics of deimplementation: the rise and decline of the "counseling and testing" paradigm for HIV prevention at the US Centers for Disease Control and Prevention. Milbank Q. 2016;94(1):126-62. https://doi.org/10.1111/1468-0009.12183.

118. Kamb ML, Fishbein M, Douglas JM Jr, et al., Project RESPECT Study Group. Efficacy of risk-reduction counseling to prevent human immunodeficiency virus and sexually transmitted diseases: a randomized controlled trial. JAMA. 1998;280(13):1161-1167.

119. Lin JS, Whitlock E, O'Connor E, Bauer V. Behavioral counseling to prevent sexually transmitted infections: a systematic review for the US Preventive Services Task Force. Ann Intern Med. 2008;149(7):497-508.

120. Metcalf CA, Douglas JM Jr, Malotte CK, et al., RESPECT-2 Study Group. Relative efficacy of prevention counseling with rapid and standard HIV testing: a randomized, controlled trial (RESPECT-2). Sex Transm Dis. 2005;32(2):130-138.

121. Metsch LR, Feaster DJ, Gooden L, et al. Effect of risk-reduction counseling with rapid HIV testing on risk of acquiring sexually transmitted infections: the AWARE randomized clinical trial. JAMA. 2013;310(16):1701-10. https://doi.org/10.1001/jama. 2013.280034.

122. Koblin B, Chesney M, Coates T, et al. Effects of a behavioral intervention to reduce acquisition of HIV infection among men who have sex with men: the EXPLORE randomized controlled study. Lancet. 2004;364(9428):41-50. https://doi.org/10.1016/ S0140-6736(04)16588-4. 
123. Koblin BA, Husnik MJ, Colfax G, et al. Risk factors for HIV infection among men who have sex with men. AIDS. 2006;20(5):731-9. https://doi.org/10.1097/01.aids.0000216374. 61442.55 .

124. Kalichman SC, Zohren L, Eaton LA. Setting the bar high or setting up to fail? Interpretations and implications of the EXPLORE Study (HPTN 015). AIDS Behav. 2014;18(4):625-33. https://doi. org/10.1007/s10461-013-0603-0.

125. Koblin BA, Mansergh G, Chesney M, Coates T. Moving the bar to the right place: positioning interventions in HIV prevention. AIDS Behav. 2014;18(4):634-7. https://doi.org/10.1007/ s10461-013-0607-9.

126. Wolitski RJ, Henny KD, Lyles CM, et al. Evolution of HIV/AIDS prevention programs-United States, 1981-2006. MMWR Morb Mortal Wkly Rep. 2006;55(21):597-603.

127. Frieden TR, Das-Douglas M, Kellerman SE, Henning KJ. Applying public health principles to the HIV epidemic. N Engl J Med. 2005;353(22):2397-402. https://doi.org/10.1056/NEJMsb0531 33

128. Frieden TR, Foti KE, Mermin J. Applying public health principles to the HIV epidemic - how are we doing? N Engl J Med. 2015;373(23):2281-7. https://doi.org/10.1056/NEJMms1513641.

129. Goosby E, Dybul M, Fauci AS, et al. The United States President's Emergency Plan for AIDS Relief: a story of partnerships and smart investments to turn the tide of the global AIDS pandemic. J Acquir Immune Defic Syndr. 2012;60(Suppl 3):S51-6.

130. Fauci AS, Eisinger RW. PEPFAR -15 years and counting the lives saved. N Engl J Med. 2018;378:314-6. https://doi.org/10. 1056/NEJMp1714773.

131. Institute of Medicine. Evaluation of PEPFAR. Washington, DC: National Academies Press; 2013. https://doi.org/10.17226/ 18256.

132. HIV.gov. The Affordable Care Act and HIV/AIDS. Washington, DC: US Department of Health \& Human Services; 2021. https://www.hiv.gov/federal-response/policies-issues/the-affor dable-care-act-and-hiv-aids. Accessed 30 Sep 2021.

133. Office of National AIDS Policy. National HIV/AIDS Strategy for the United States. Washington, DC: The White House; 2010. https://www.hiv.gov/federal-response/hiv-national-strategic-plan/ national-hiv-aids-strategies-2010-2020. Accessed 30 Sep 2021.

134. Grossman CI, Purcell DW, Rotheram-Borus MJ, Veniegas R. Opportunities for HIV combination prevention to reduce racial and ethnic health disparities. Am Psychol. 2013;68(4):237-46. https://doi.org/10.1037/a0032711.

135. Kurth AE, Celum C, Baeten JM, Vermund SH, Wasserheit JN. Combination HIV prevention: significance, challenges, and opportunities. Curr HIV/AIDS Rep. 2011;8(1):62-72. https:// doi.org/10.1007/s11904-010-0063-3.

136. Gardner EM, McLees MP, Steiner JF, Del Rio C, Burman WJ. The spectrum of engagement in HIV care and its relevance to test-and-treat strategies for prevention of HIV infection. Clin Infect Dis. 2011;52:793-800.

137. Kay ES, Batey DS, Mugavero MJ. The HIV treatment cascade and care continuum: updates, goals, and recommendations for the future. AIDS Res Ther. 2016;13:35. https://doi.org/10.1186/ s12981-016-0120-0.

138. Mugavero MJ, Amico KR, Horn T, Thompson MA. The state of engagement in HIV care in the United States: from cascade to continuum to control. Clin Infect Dis. 2013;57(8):1164-71. https://doi.org/10.1093/cid/cit420.

139. Fauci AS, Marston HD. Ending the HIV-AIDS pandemic-follow the science. N Engl J Med. 2015;373(23):2197-9. https:// doi.org/10.1056/NEJMp1502020.

140. Das P, Horton R. Beyond the silos: integrating HIV and global health. Lancet. 2018;392(10144):260-261. https://doi.org/10. 1016/S0140-6736(18)31466-1.
141. Eisinger RW, Fauci AS. Ending the HIV/AIDS pandemic. Emerg Infect Dis. 2018;24(3):413-6. https://doi.org/10.3201/eid2403. 171797.

142. Fauci AS, Redfield RR, Sigounas G, Weahkee MD, Giroir BP. Ending the HIV epidemic: a plan for the United States. JAMA. 2019;321(9):844-5. https://doi.org/10.1001/jama.2019.1343.

143. Williams B, Wood R, Dukay V, et al. Treatment as prevention: preparing the way. J Int AIDS Soc. 2011;14(Suppl 1):S6. https:// doi.org/10.1186/1758-2652-14-S1-S6.

144. Gamble T, Branson B, Donnell D, et al. Design of the HPTN 065 (TLC-Plus) study: a study to evaluate the feasibility of an enhanced test, link-to-care, plus treat approach for HIV prevention in the United States. Clin Trials. 2017;14(4):322-32. https:// doi.org/10.1177/17407745177116820.

145. FHI 360. HPTN 065-TLC-Plus: a study to evaluate the feasibility of an enhanced test, link to care, plus treat approach for HIV prevention in the United States, study summary. HPTN Newsletter. https://www.hptn.org/research/studies/77. Accessed 30 Sep 2021.

146. New York City Department of Health and Mental Hygiene. The Bronx Knows HIV testing initiative final report. https://www1. nyc.gov/assets/doh/downloads/pdf/ah/bronx-knows-summaryreport.pdf. Accessed 30 Sep 2021.

147. Greenberg AE, Hader SL, Masur H, Young AT, Skillicorn J, Dieffenbach CW. Fighting HIV/AIDS in Washington. DC Health Affairs. 2009;28(6):1677-87. https://doi.org/10.1377/hlthaff. 28.6.1677.

148. Greenberg AE, Purcell DW, Gordon CM, et al. NIH support of centers for AIDS research and department of health collaborative public health research: advancing CDC's enhanced comprehensive HIV prevention planning project. J Acquir Immune Defic Syndr. 2013;64:S1-6.

149. Branson B, Chavez P, Hanscom B, et al. Expanding hospital human immunodeficiency virus testing in the Bronx, New York and Washington, District of Columbia. Clin Infect Dis. 2018;66(10):1581-7. https://doi.org/10.1093/cid/cix1053.

150. Greenberg AE, Purcell DW, Gordon CM, et al. Addressing the challenges of the HIV continuum of care in high-prevalence cities in the United States. J Acquir Immune Defic Syndr. 2015;69:S1-7.

151. Greenberg AE, Gordon CM, Purcell DW. Promotion of research on the HIV continuum of care in the United States: the CFAR HIV continuum of care/ECHPP working group. J Acquir Immune Defic Syndr. 2017;74(Suppl 2):S75-80. https://doi.org/10.1097/ QAI.0000000000001243.

152. Purcell DW, McCray E, Mermin J. The shift to high-impact HIV prevention by health departments in the United States. Public Health Rep. 2016;131(1):7-10. https://doi.org/10.1177/00333 5491613100104.

153. Flores SA, Purcell DW, Fisher HH, et al. Shifting resources and focus to meet the goals of the national HIV/AIDS strategy: the enhanced comprehensive HIV prevention planning project, 2010-2013. Public Health Rep. 2016;131(1):52-8. https://doi. org/10.1177/003335491613100111.

154. Fisher HH, Hoyte T, Flores SA, et al. Evaluation framework for HIV prevention and care activities in the enhanced comprehensive HIV prevention planning project, 2010-2013. Public Health Rep. 2016;131(1):67-75. https://doi.org/10.1177/0033354916 13100113.

155. Carey JW, LaLota M, Villamizar K, et al. Using high-impact HIV prevention to achieve the National HIV/AIDS Strategic goals in Miami-Dade County, Florida: a case study. J Public Health Manag Pract. 2015;21(6):584-93. https://doi.org/10.1097/PHH. 0000000000000321.

156. Ryan B. "Rick Scott had us on lockdown:" How Florida said no to $\$ 70 \mathrm{~m}$ for HIV crisis. The Guardian. Sep 11 2019. https:// www.theguardian.com/us-news/2019/sep/11/florida-hiv-rickscott-republican-governor. Accessed 30 Sep 2021. 
157. Centers for Disease Control and Prevention. HIV Surveillance Report, 2019; vol.32: Table 22. https://www.cdc.gov/hiv/pdf/ library/reports/surveillance/cdc-hiv-surveillance-report-2018updated-vol-32.pdf. Accessed 30 Sep 2021.

158. Cohen J. "We're in a mess." Why Florida is struggling with an unusually severe HIV/AIDS problem. Science. 2018. https://doi. org/10.1126/science.aau4558.

159. Centers for Disease Control and Prevention (CDC). High-impact HIV prevention: CDC's approach to reducing HIV infections in the United States. Atlanta, GA: CDC; 2011.

160. Gaist P, Stirratt MJ. The roles of behavioral and social science research in the fight against HIV/AIDS: a functional framework. J Acquir Immune Defic Syndr. 2017;75(4):371-81. https://doi. org/10.1097/QAI.0000000000001399.

161. Deeks SG, Lewin SR, Havlir DV. The end of AIDS: HIV infection as a chronic disease. Lancet. 2013;382(9903):1525-33. https://doi.org/10.1016/S0140-6736(13)61809-7.

162. Eaton LA, Huedo-Medina TB, Kalichman SC, et al. Meta-analysis of single-session behavioral interventions to prevent sexually transmitted infections: implications for bundling prevention packages. Am J Public Health. 2012;102(11):e34-44.

163. Larsen KR, Michie S, Hekle EB, et al. Behavior change interventions: the potential of ontologies for advancing science and practice. J Behav Med. 2017;40:6-22. https://doi.org/10.1007/ s10865-016-9768-0.

164. Green A, Kolar K. Engineering behavior change in an epidemic: the epistemology of NIH-funded HIV prevention science. Sociol Health Illn. 2015;37(4):561-77. https://doi.org/10.1111/14679566.12210.

165. Sarno EL, Macapagal K, Newcomb ME. "The main concern is HIV, everything else is fixable": indifference toward sexually transmitted infections in the era of biomedical HIV prevention. AIDS Behav. 2021;25:2657-60. https://doi.org/10.1007/ s10461-021-03226-8.

166. Malekinejad M, Blodgett J, Horvath H, et al. Change in condom use in populations newly aware of HIV diagnosis in the United States and Canada: a systematic review and meta-analysis. AIDS Behav. 2021;25(6):1839-55. https://doi.org/10.1007/ s10461-020-03113-8.

167. Miranda G. STDs reach all-time high for sixth consecutive year in the US: is your state in the top 10? USA Today. June 15, 2021. https://www.yahoo.com/news/stds-reach-time-high-sixth-19495 3476.html. Accessed 21 June 2021.

168. Padian NS, McCoy SI, Manian S, Wilson D, Schwartländer B, Bertozzi SM. Evaluation of large-scale combination HIV prevention programs: essential issues. J Acquir Immune Defic Syndr. 2011;58(2):e23-8. https://doi.org/10.1097/QAI.0b013e3182 27 af 37.
169. Padian NS, Isbell MT, Russell ES, Essex M. The future of HIV prevention. J Acquir Immune Defic Syndr. 2012;60(Suppl 2):S22-6. https://doi.org/10.1097/QAI.0b013e31825b7100.

170. Blanchard JF, Aral SO. Program science: an initiative to improve the planning, implementation and evaluation of HIV/sexually transmitted infection prevention programs. Sex Transm Infect. 2011;87:2-3.

171. Becker M, Mishra S, Aral S, et al. The contributions and future direction of program science in HIV/STI prevention. Emerg Themes Epidemiol. 2018;15:7. https://doi.org/10.1186/ s12982-018-0076-8.

172. Aral SO, Blanchard J. Biomedical and social dimensions of HIV prevention. Am J Public Health. 2012;102(9):e9-10. https://doi. org/10.2105/AJPH.2012.300886.

173. Choi SKY, Holtgrave DR, Bacon J, et al. Economic evaluation of community-based HIV prevention programs in Ontario: Evidence of effectiveness in reducing HIV infections and health care costs. AIDS Behav. 2016;20:1143-56. https://doi.org/10.1007/ s10461-015-1109-8.

174. Office of the Surgeon General. Confronting Health Misinformation: The US Surgeon General's Advisory on Building a Healthy Information Environment. Washington, DC: US Public Health Service; 2021. https://www.hhs.gov/sites/default/files/surgeongeneral-misinformation-advisory.pdf. Accessed 30 Sep 2021.

175. Fee E, Fox DM, editors. AIDS: the burdens of history. Berkeley, CA: University of California Press; 1988.

176. Fee E, Fox DM, editors. AIDS: the making of a chronic disease. Oakland, CA: University of California Press; 1991.

177. Johnson S. Extra life: a short history of living longer. New York: Riverhead; 2021.

178. Landau S. People count: contact-tracing apps and public health. Cambridge, MA: MIT Press; 2021.

179. Larson HJ. Stuck: how vaccine rumors start-and why they don't go away. New York: Oxford University Press; 2020.

180. McGoey L. No such thing as a free gift: the Gates Foundation and the price of philanthropy. London: Verso; 2015.

181. McGoey L. The unknowers: how strategic ignorance rules the world. London: Zed; 2019.

182. Kucharski A. The rules of contagion: why things spread-and why they stop. New York: Basic Books; 2020.

183. Tulchinsky TH, Varavikova EA, editors. The new public health. 2nd ed. Amsterdam, NL: Elsevier; 2009.

184. Brownson RC, Baker EA, Leet TL, Gillespie KN, True WR. Evidence-based public health. 2nd ed. New York: Oxford University Press; 2011.

Publisher's Note Springer Nature remains neutral with regard to jurisdictional claims in published maps and institutional affiliations. 